\title{
Quand I'habit fait le moine: The Symbolism of the kāsāya in Sōtō
} zen

In: Cahiers d'Extrême-Asie, Vol. 8, 1995. pp. 335-369.

Citer ce document / Cite this document :

Faure Bernard. Quand l'habit fait le moine: The Symbolism of the kāsāya in Sōtō zen. In: Cahiers d'Extrême-Asie, Vol. 8, 1995. pp. 335-369.

doi : 10.3406/asie.1995.1101

http://www.persee.fr/web/revues/home/prescript/article/asie_0766-1177_1995_num_8_1_1101 


\section{Résumé}

La sacralisation de trésors dynastiques, d'objets de culte, de reliques, de talismans et de diagrammes est un phénomène politique et religieux qu 'on peut dire universel. Sur sa valeur de légitimation dans le contexte chinois, Anna Seidel avait écrit quelques-unes de ses études les plus pénétrantes. Avec des limites bien tracées, le présent article se voudrait une prise de relais : dans une monographie du Hōbōgirin encore inédite, Anna Seidel avait suivi les vicissitudes de la transmission (purement fictive) de la robe du Buddha durant les débuts du Chan en Chine. Sur base de cette recherche qu'il décrit brièvement, l'auteur pousse ici l'enquête du côté japonais, tout en gardant dans sa perspective la question fondamentale : pourquoi le vêtement monastique est-il devenu le symbole par excellence du Dharma, surclassant d'autres symboles et reliques, et occupant une place éminente dans I 'imaginaire bouddhique?

Du côté japonais, son information repose surtout sur quelques chapitres hautement liturgiques et ecclésiastiques du Shōbōgenzō de Dōgen (1200-1253) et sur quelques textes de son Ecole, notamment des extraits du Denkōroku de Keizan (1268-1325) et d'autres textes, plus tardifs, réunis dans la section Shingi du "Supplément aux Ecrits de I 'Ecole Sōtō ". Une dernière source enfin est constituée par quelques Kirigami initiatiques du Sōtō, souvent proches du tantrisme Mikkyō.

Dōgen héritait de traditions complexes concernant l'habit monastique. II était d'abord concerné par l'exaltation apocryphe du vêtement du Buddha, gage de la filiation légitime (mais non sans accrocs) des patriarches du Dhyāna en Inde et en Chine qui aboutissait au sixième patriarche chinois, Huineng ( $\mathrm{m}$. en 713). II ne fut pas indifférent non plus aux divergences dont le kāsāya et notamment sa confection matérielle (haillons ou brocards, coton ou soie) faisaient l'objet dans différentes traditions du Vinaya : celle de Daoxuan (596-667) et celle de Yijing (635-713). Enfin, il connaissait l'assimilation bien établie entre ordination monastique (concrétisée par la prise d'habit) et sacre royal (kanjō).

Dōgen, d'autre part, semble porté par un effort de synthèse mystique : identité de tous les kāsāya du Buddha entre eux, identification de tout kesa monastique orthodoxe (donc Zen) au kāsāya du Buddha, identification du kāsāya au Dharma, identification enfin du moine à son habit. Dans l'exaltation de l'habit qui distingue le religieux complètement ordonné des laïcs profanes, ne retrouve-t-on pas la distinction, exacerbée dans le Grand Véhicule, entre religieux (shukke) et profane?

Dōgen passe de la richesse symbolique de la complémentarité (à la la manière des insignes fu chinois en deux parties) entre le Dharma et son vêtement, "robe de délivrance", à une sublimation de la robe au point de la rendre immatérielle et en quelque sorte supérieure au Dharma. Une telle abstraction aide en fait la dissémination de la robe monastique.

L 'exaltation du kāsāya du Buddha est inséparable du riche potentiel magique qu 'il dégage : son poids, son extension, qui peuvent être incommensurables, comme la taille du Buddha. Mais, ce potentiel miraculeux affecte tout kāsāya. La fantaisie d'Utpalavarnā, prostituée, revêtant une robe de nonne, la conduira à la sainteté par l'effet du vêtement. En outre, Dōgen est confronté au jeu politique dont le kāsāya fait l'objet, jeu politique que reflète son adoption en Chine comme trésor national par des empereurs Tang tandis qu'avant eux Wu Zetian honorait des religieux par des robes de pourpre. Du côté japonais, on perçoit la relation ambiguë chez Dōgen de ce kāsāya vis-à-vis des trésors impériaux et l'embarras du même Dōgen, honoré d'une robe de grand prix par l'empereur Go-Saga.

Les écrits postérieurs à Dōgen développent encore l'analyse du symbolisme du kesa. Tous ses aspects sont envisagés : nombre de pièces constitutives, couleurs, assimilation au riche thème du champ de mérite, aux reliques de contact et à leurs vertus, au cosmogramme du mandala, aux multiples facettes du siège de l'illumination (bodhimanda), au stūpa et à ses rites, et pour finir — et ici l'enquête devient plus anthropologique - à la matrice.

Du kesa, assimilé au placenta et à la naissance, au kesa, symbole d'ordination et de sacre, et donc de renaissance, il y a continuité. Cette continuité dans le Zen concorde avec la doctrine bouddhique des deux vérités comme avec la vision complémentaire et quasi talismanique de la cosmologie traditionnelle. D 'autre part, par une virevolte "rhétorique" du Zen, déjà observée ailleurs, la sacralisation $\mathrm{n}$ 'empêche pas dans la pratique quotidienne une certaine désinvolture vis-à-vis de l'objet sacré, en l'occurrence le froc monacal. Si la ritualisation du froc a contribué à renforcer la supériorité des religieux sur les laïcs, la contradiction qu 'on a voulu voir entre un vêtement fait de haillons et un vêtement de soie (avec le massacre de vers à soie que sous-entend sa fabrication) se résout peut-être dans la 
dualité du Buddha lui-même, ascète et souverain universel dont le Grand Véhicule exalte le corps glorieux. 


\title{
QUAND L'HABIT FAIT LE MOINE : \\ THE SYMBOLISM OF THE $K \bar{A} S \bar{A} Y A A$ IN SŌTŌ ZEN
}

\author{
Bernard FAURE
}

La sacralisation de trésors dynastiques, d'objets de culte, de reliques, de talismans et de diagrammes est un phénomène politique et religieux qu'on peut dire universel. Sur sa valeur de légitimation dans le contexte chinois, Anna Seidel avait écrit quelques-unes de ses études les plus pénétrantes. Avec des limites bien tracées, le présent article se voudrait une prise de relais : dans une monographie du Hōbōgirin encore inédite, Anna Seidel avait suivi les vicissitudes de la transmission (purement fictive) de la robe du Buddha durant les débuts du Chan en Chine. Sur base de cette recherche qu'il décrit brièvement, l'auteur pousse ici l'enquête du côté japonais, tout en gardant dans sa perspective la question fondamentale : pourquoi le vêtement monastique est-il devenu le symbole par excellence du Dharma, surclassant d'autres symboles et reliques, et occupant une place éminente dans l'imaginaire bouddhique?

Du côté japonais, son information repose surtout sur quelques chapitres hautement liturgiques et ecclésiastiques du Shōbōgenzō de Dōgen (1200-1253) et sur quelques textes de son Ecole, notamment des extraits du Denkōroku de Keizan (12681325) et d'autres textes, plus tardifs, réunis dans la section Shingi $d u$ "Supplément aux Ecrits de l'Ecole Sōtō". Une dernière source enfin est constituée par quelques Kirigami initiatiques du Sōtō, souvent proches du tantrisme Mikkyō.

Dögen héritait de traditions complexes concernant l'habit monastique. Il était d'abord concerné par l'exaltation apocryphe du vêtement du Buddha, gage de la filiation légitime (mais non sans accrocs) des patriarches du Dhyäna en Inde et en Chine qui aboutissait au sixième patriarche chinois, Huineng (m. en 7l3). Il ne fut pas indifférent non plus aux divergences dont le kāsāya et notamment sa confection matérielle (haillons ou brocards, coton ou soie) faisaient l'objet dans différentes traditions du Vinaya : celle de Daoxuan (596-667) et celle de Yijing (635-713). Enfin, il connaissait l'assimilation bien établie entre ordination monastique (concrétisée par la prise d'habit) et sacre royal (kanjō).

Dōgen, d'autre part, semble porté par un effort de synthèse mystique : identité de tous les kāșāya du Buddha entre eux, identification de tout kesa monastique orthodoxe (donc Zen) au

Cahiers d'Extrême-Asie 8 (1995) : 335-369. 
kāṣāya du Buddha, identification du kāṣāya au Dharma, identification enfin du moine à son habit. Dans l'exaltation de l'habit qui distingue le religieux complètement ordonné des laïcs profanes, ne retrouve-t-on pas la distinction, exacerbée dans le Grand Véhicule, entre religieux (shukke) et profane?

Dōgen passe de la richesse symbolique de la complémentarité (à la la manière des insignes fu chinois en deux parties) entre le Dharma et son vêtement " robe de délivrance", à une sublimation de la robe au point de la rendre immatérielle et en quelque sorte supérieure au Dharma. Une telle abstraction aide en fait la dissémination de la robe monastique.

$L$ 'exaltation du kāșāya $d u$ Buddha est inséparable du riche potentiel magique qu'il dégage: son poids, son extension, qui peuvent être incommensurables, comme la taille du Buddha. Mais, ce potentiel miraculeux affecte tout kāșāya. La fantaisie d'Utpalavarnā, prostituée, revêtant une robe de nonne, la conduira à la sainteté par l'effet du vêtement. En outre, Dōgen est confronté au jeu politique dont le kāșāya fait l'objet, jeu politique que reflète son adoption en Chine comme trésor national par des empereurs Tang tandis qu'avant eux $W u$ Zetian honorait des religieux par des robes de pourpre. Du côté japonais, on perçoit la relation ambiguë chez Dōgen de ce kāșāya vis-à-vis des trésors impériaux et l'embarras du même Dögen, honoré d'une robe de grand prix par l'empereur Go-Saga.

Les écrits postérieurs à Dōgen développent encore l'analyse du symbolisme du kesa. Tous ses aspects sont envisagés : nombre de pièces constitutives, couleurs, assimilation au riche thème du champ de mérite, aux reliques de contact et à leurs vertus, au cosmogramme du mandala, aux multiples facettes du siège de l'illumination (bodhimaṇạ), au stūpa et à ses rites, et pour finir-et ici l'enquête devient plus anthropologique-à la matrice.

Du kesa, assimilé au placenta et à la naissance, au kesa, symbole d'ordination et de sacre, et donc de renaissance, il y a continuité. Cette continuité dans le Zen concorde avec la doctrine bouddhique des deux vérités comme avec la vision complémentaire et quasi talismanique de la cosmologie traditionnelle. D'autre part, par une virevolte "rhétorique" du Zen, déjà observée ailleurs, la sacralisation n'empêche pas dans la pratique quotidienne une certaine désinvolture vis-à-vis de l'objet sacré, en l'occurrence le froc monacal. Si la ritualisation du froc a contribué à renforcer la supériorité des religieux sur les laïcs, la contradiction qu'on a voulu voir entre un vêtement fait de haillons et un vêtement de soie (avec le massacre de vers à soie que sous-entend sa fabrication) se résout peut-être dans la dualité du Buddha lui-même, ascète et souverain universel dont le Grand Véhicule exalte le corps glorieux. 
This discussion of the Buddhist monastic robe [Sk. kāsāya, J. kesa 袈装] is a supplement to "Den'e" 傳衣 ["Transmission of the robe"], an essay written by Anna Seidel almost fifteen years ago. At the time, I was myself working on a dissertation on early Chan, and the question of Chan Dharma transmission became the topic of many lively discussions between us.' In her essay, she established many insightful connections between the early Chan tradition and Taoist and Confucian notions of lineage. She continued to explore these connections in two articles, “Kokuhō" 國烡 [1981] and "Dynastic Treasures and Taoist Sacraments" [1983]. ${ }^{2}$

There is nothing to add today to what Anna Seidel wrote about the transmission of the robe in Chan/Zen 禪. Her work in that domain, as in others, remains unequalled, and I hope an English translation of this essay will soon appear. Taking my cue from this essay, I will elaborate on an aspect which came to play a prominent role in Japanese Buddhism and particularly in medieval Zen: the symbolism of the kāsāya. I will therefore shift the focus from early Chan to Dōgen 道元 (1200-1253) and the later Sōtō 曹洞宗 tradition, as represented in particular by the initiation documents called kirigami (var. kirikami) 切紙. This inquiry will perhaps help us answer the questions: Why was it precisely the robe that was chosen as the symbol of the Dharma, among other symbols or relics? How does it differ from these other symbols? How did it come to occupy such a central place in the Buddhist imagination?

It is of course because the käsăya was one of the few things that a monk was authorized to possess that it came to acquire a richly overlaid symbolic meaning. ${ }^{3}$ However, its basic symbolism was one of austerity and simplicity: the wearing of a $k \bar{a} s \hat{a} y a$ is the first of the twelve (or thirteen) dhütāinga, the pāmsukūlikānga. ${ }^{4}$ The robe is often called funzō-e 翼掃衣 (from the Sanskrit pāmsukūla-kāşāya, lit. "robe to sweep excrement," probably an abbreviation for "robe [composed of tattered cloths, which have been used] to sweep [all kinds of junk, including] excrement").

1 "Den'e" will appear in Hōbōgirin 8 (forthcoming).

${ }^{2}$ Anna Seidel, "Kokuhō: Note à propos du terme 'Trésor National' en Chine et au Japon," BEFEO 69 (1981): 229-261; "Dynastic Treasures and Taoist Sacraments: Taoist Roots in the Apocrypha," in Michel Strickmann, ed., Tantric and Taoist Studies in Honour of R. A. Stein, vol. 2, Mélanges Chinois et Bouddhiques XXI (1983): 291-371.

${ }^{3}$ Part of my information on the symbolic and material aspects of the kasaya derives from a catalogue edited by Alan Kennedy, entitled: Manteau de nuages: Kesa japonais, XVIII ${ }^{-}$ $X I X^{e}$ siècles, Paris: Réunion des Musées Nationaux, 1991. This catalogue commemorated an exhibition of Chinese and Japanese kāsāya, held by the Association pour l'Etude et la Documentation des Textiles d'Asie led by Krishnā Riboud, in Paris and Lyon in 1991-1992, and at Shōkokuji in Kyōto in October 1994.

${ }^{4}$ See I-tsing [Yijing], A Record of the Buddhist Religion as Practised in India and the Malay Archipelago (A. D. 671-695), transl. J. Takakusu, Oxford: Clarendon, 1896, repr. Delhi: Munshiram Manoharlal, 1966. 
The Buddhist tradition lists six, eight, or eighteen authorized objects. ${ }^{5}$ In India as in East Asia, the term kassayya, referring to the original colour of the robe, was applied to three kinds of clothes. The inner robe (J. andae 安陀會, from the Sanskrit antarvāsa) was a five-strip kāsāya worn for work and sleep. The outer robe, hanging from the left shoulder, is the uttarasō 優多羅僧 (Sk. uttarāsanga), a sevenstrip kāsāya worn for ordinary activities such as ritual (sūtra rcadings, ctc.). Finally, the outer robe (sōgyarie 僧伽梨衣, Sk. samghāti ), or “great robe" (daie 大衣), is a nine-strip kāsayya worn on more formal occasions, when going outside of the monastery for alms or preaching. Thus, the first robe is worn privately, the second in the company of other monks, and the third in the presence of laymen. According to the Lüzong huiyuan 律宗會元, the three robes also correspond to the "three times," i.e., winter, summer, and spring: in winter one wears the double robe, in summer the light robe, and in spring the medium robe. ${ }^{6}$ According to Dōgen, there is also a daily gradation in winter time: the five-strip kâsâya is worn during the evening; the seven-strip kạsăya around midnight; and the nine-strip käsaaya during the coldest part of the morning. " The samghäti-kāsâya, also called "double kāsâya," is in turn of nine kinds: with nine, thirteen, fifteen, seventeen, nineteen, twenty-one, twenty-three and twenty-five strips. The three types of robes can be worn separately, or together when it is cold. However, their function came to differ. In actual practice, it seems that, unlike in India where the three robes were supposed to be worn together, in Japan, where their symbolic function became predominant, they came to be worn separately.

In China, with the rise of the Chan school in the seventh and eighth centuries, the $k \bar{a}$ âya came to be perceived above all as a symbol or material counterpart of the tcaching of the Buddha. The compound yibuo (J. ehatsu 衣鉢, ifu) "robe and bowl," has come to mean "teaching transmitted by a master to his disciples" in Chinese. As

\footnotetext{
5 Yijing 義淨 (635-713) lists six "requisites": the three robes, the bowl (pätra), the sittingmat (nisidana), and the water-pourer (parisravana); he also enumerates thirteen "necessities" (including the above). See I-tsing, A Record of the Buddhist Religion, 54-55. The Fanwang jing 婪網経 [T. 24, 1484: 1008a] gives a total of eighteen things. See also

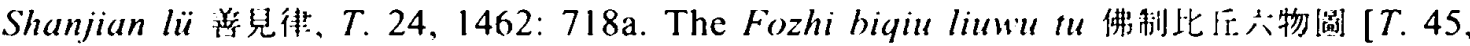
1900], an illustrated work by Yuanzhao 元照 (1048-1116), in the tradition of Daoxuan's 道宣 (596-667) Nanshan lü 献山律 school, still gives six things. In the Chanyuan qinggui 辣誃清規、 the list is already quite different from that given in Indian sources. See Sōtōshũ zensho

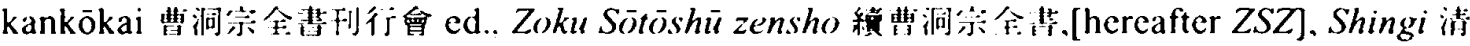
规. 1976: 869. The Chan/Zen list is again rather different, for it reflects local customs: it goes far beyond the traditional three robes and one bowl. The Zen scholar Mujaku Dōchū 無著道忠 (1653-1744) lists for instance ninety-six objects (including, it is true, collective properties such as chairs, etc.). See Ishikawa Rikizan 在川力川 "Chūsei Sōtōshū kirigami no bunrui shiron 中世曹洞宗切紙の分類史論 (6),”Komazawa Daigaku bukkyo gakubu ronshü 16 (1985): 105. However, in all these sources, the kāsāya always comes first.

${ }^{6} \mathrm{ZZ} 105,414 \mathrm{~b}$.

${ }^{7}$ T. 82, 2582: 49a.
} 
is well known, one of the founding myths of Chan concerns Sākyamuni's transmission of the "true dharma eye" (zhengfayan 此法眼) to his disciple Mahākāśyapa: we are told that Sākyamuni, desiring to designate a successor, held up a flower in front of the assembly, and only Kāśyapa smiled. This legend was complemented by that of the transmission of Śākyamuni's kāsāya to Kāśyapa. In her essay, Anna Seidel described the ideological elaboration that led to the theory of the "transmission of the robe," as it found its classical form with Heze Shenhui 河澤 神會 (684-758). In his relentless effort to establish himself as the seventh Chan patriarch, Shenhui argued that after the transmission of the Dharma and the robe to Hongren's 弘忍 (601-674) disciple Huineng 慧能 (d. 713), the kāsãya was no longer transmitted. Shenhui criticized the value of other insignia and their transmission to more than one person; he assimilated the Chan patriarch to the universal monarch (cakravartin) and to the Buddha himself, arguing that there can never be more than one patriarch in the world at a given time.

From Anna Seidel's analysis, it appears that the Chan tradition was never able to prove whether the robe transmitted to Huineng was that of the Buddha himself, of the twenty-fourth patriarch Simhabhiksu, or of Bodhidharma. The implicit belief that it is the same robe is constantly belied by various accounts, according to which the transmission was interrupted in India with Simhabhikșu or his successor Basiasita. In later Chan chronicles, we are told that the kâsāya was stolen several times. The fact that it was apparently never recovered implies the existence of several kāsa âya.

Furthermore, the meaning of the transmission to Kâsyapa changed. The early Buddhist tradition says that the robe was simply entrusted to Kâśyapa, with the mission to give it to the future Buddha Maitreya. According to Xuanzang 玄奖 (602664), Kāśyapa did not put on the robe of the Buddha, but held it in his arms, in the position of a man who receives or offers-a mere intermediary between the past and future Buddhas. ${ }^{8}$ However, the Chan tradition claims that it was given to Kāśyapa himself, as proof of his enlightenment-just as in the cases of the transmission from Bodhidharma to Huike 慧可, or from Hongren to Huineng. According to this new interpretation, the robe was subsequently transmitted to Ānanda, making it difficult for Maitreya to receive it from Kāśyapa. The ambiguity of the Chan/Zen tradition on this point undermines logically the status of Kāśyapa and of the Chan lineage, while reinforcing it symbolically. ${ }^{9}$

The only Chan texts that actually claim that the robe given by Bodhidharma to Huike was the same transmitted by the Buddha to Kāśyapa are the Zutangji 祖堂集 and the Jingde Chuandenglu 景德傳燈録 (T. 2076). ${ }^{10}$ Dōgen also argues that

${ }^{8}$ See Marinus Willem de Visser, The Arhats in China and Japan, Berlin: Oesterheld, 1923: 93.

${ }^{9}$ See Theodore Griffith Foulk, The 'Ch'an School' in the Buddhist Monastic Tradition, Ph.D., Univ. of Michigan, 1987.

${ }^{10}$ See Foulk, 239; but according to Anna Seidel, the Jingde Chuandenglu does say that the robe transmitted to Huike is that of the Buddha; see T. 51, 2076: 219. 
Huineng's robe was the same one that had been transmitted to Kāśyapa. He implies that this kāsayya is the very same one that he himself received from his master Tiantong Rujing 天童如鿇 (1162-1227), although he also seems to believe that the $k a \bar{s} a \bar{y} a$ will eventually be transmitted by Kāsyapa to Maitreya. "Speaking of the size of the kāssayya, Dōgen criticizes the traditional story of the transmission from Mahākāśyapa to Maitreya, as told for instance in the Dazhidulun 大智度論. According to this story, the coming of Maitreya marks the beginning of a new kalpa, a perfect time, when the lifespan of men and their bodily size are very great. Thus Kāśyapa, who lived at a time of degeneration, appears to Maitreya's astonished disciples as a Lilliputian Arhat, and the kạsāya that he transmits can hardly cover two fingers of Maitreya. ${ }^{12}$ Dōgen writes: "It is generally said that the bodily size of men varies as a function of their lifespan-which can vary from 80,000 years to one hundred years. Some say that 80,000 years and one hundred years are different, others that they are the same. The latter view is that of the correct transmission. The size of a man's body and that of a Buddha's body differ greatly. The size of a man's body can be measured, that of a Buddha's body in the last analysis cannot. This is why the kāsāya of the Buddha Kāśyapa is neither too long nor too large for the Buddha Śăkyamuni to wear, while that of the Buddha Śăkyamuni is neither too short nor too small for the Tathāgata Maitreya to wear."13 Interestingly, Dōgen calls Kāśyapa a Buddha, like Śākyamuni and Maitreya. Dōgen seems to be (conveniently?) confusing the past Buddha Kāśyapa, predecessor of Sākyamuni, with Sākyamuni's disciple [Mahā]kāśyapa. Kāśyapa is no longer an epigon, an intermediary-but a full-fledged Buddha, and his transmission of the kāsāya, going hand in hand with that of the Dharma, implies that he is the master of Maitreya. Thus, all the patriarchs become Buddhas-not only the future Buddha. ${ }^{14}$

Mujaku Dōchū 無着道忠 points out the confusion in Chan/Zen literature between at least two kinds of robes: a) the kāsāya embroidered with gold (often called soggari-e, from the Sk. samghātí), received from his aunt and adoptive mother, Mahāprajāpatī Gautami; and b) the robe made from tattered cloth [funzōe, Sk.

"Although Dōgen's kāṣāya was held as one of the sacra of the Sōtō tradition, it could hardly boast of an Indian origin. Even its Chinese origin is uncertain: according to a document from Kōfukuji 廣福寺 in Kumamoto prefecture, telling of the transmission of Dōgen's robe by Gikai 義价 (1219-1309) to Keizan Jōkin 䇪山稆瑾 (1268-1325), then by Keizan to his disciple Meihō Sotetsu 明等素哲 (1277-1350) in 1309, the käsāya was woven by the wife of a lay disciple of Dōgen and sewn by Dōgen himself. In 1248 he also sewed the

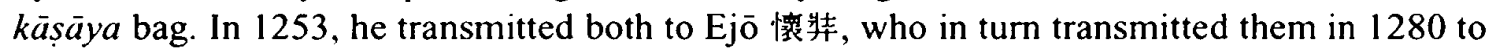
Gikai. In 1294, they passed from Gikai to Keizan, and in 1311 from Keizan to Meihō Sotetsu.

12 See Etienne Lamotte, Traité de la Grande Vertu de Sagesse, vol. I, Louvain: Bibliothèque du Muséon, 1944: 191-196 and Mujaku Dōchū, Zenrin shōkisen 禅林象器箋, Kyōto: Seishin shobō 誠信書房, 1963: 684-685.

${ }^{13}$ T. 82, 2582: 53b14-26.

${ }^{14}$ See Foulk, op. cit., 170. 
pämsuküla]. ${ }^{15}$ The author of the Shakushi hōe kun 釋氏法衣訓 is also aware of the confusion but does little to resolve it. ${ }^{16}$ Anna Seidel suggests that the transmission of this robe to Maitreya might result from a confusion between two themes: on the one hand, Śăkyamuni and Kâśyapa exchange robes; on the other hand, Kāśyapa gives to Maitreya the pämsukūla that he had received from the Buddha in exchange for his own samghàti.

This discrepancy extends to the physical description of the robe. In Dōgen's account, for instance, it affects the color of the kāsāya: "The Tathāgata always wore a flesh-colored kāsāya. This is the color of the kāsāya. The kāsāya transmitted by the first patriarch [Bodhidharma] was blue-black in color, and made of cotton cloth from India. It is now on Mount Caoxi 曹渓山, and it is the one that was transmitted through twenty-eight generations of Indian patriarchs and five generations of Chinese patriarchs." 17

Keizan Jōkin 瑩山紹瑾 (1268-1325) tries to solve the discrepancy by assuming that the Buddha transmitted several robes: "There are several other kāsa $\bar{a} y a$ of the Buddha [apart from the golden-sleeve robe]. The robe transmitted from Bodhidharma to Caoxi [Huineng] was made of blue-black cotton cloth (qiushubu 屈 眴布). When it came to China, a blue lining was added. It is now kept in the mausoleum of the sixth patriarch and is considered a national treasure..."18

\section{The symbolism of the robe in China}

It is with the establishment of the sixth patriarch Huineng (d. 713) that the patriarchal robe acquired its reputation. This story is well known and we need not dwell on it. Suffice it to say that the Dharma robe and the begging bowl of the patriarchs were not simply the "physical proof" of transmission, as most scholars believe, but were essentially, as Anna Seidel demonstrated, a kind of dynastic relics and talismans. The robe is taken usually as a simple symbol, a "token of transmission" that "expresses the faith," but precisely a token (in French, gage) is already more than a simple sign because it has a performative value, it commits (engage) the future. The robe, essentially the "robe of Dharma transmission" (chuanfayi 傳法衣, or simply “Dharma robe," fayi 法衣), is the physical representation of the teaching of a master. It is symbolic only in the etymological sense (symbolon), in the same way that the fu 符 (Taoist talisman) is a "symbol," a

\footnotetext{
is Mujaku, Zenrin shōkisen, 684.

${ }^{16}$ Shakushi hōe kun, ZSZ Shingi, 554.

17 “Kesa kudoku 袈装功徳," T. 82, 2582: 53a; see also Shakushi hōe kun, ZSZ Shingi, 553.

${ }^{18}$ Denkōroku 傅光録, T. 82, 2585: 345b18-21. But Keizan also says that Basiasita's robe was that of the Buddha, and that which will be transmitted to Maitreya. See ibid.; see also Mujaku, Zenrin shōkisen, 684.
} 
talisman, a tally. According to Jacques Gernet, "The robe is only the replica and the double of the Law." And he adds, "Whoever possesses the one possesses the other." 19 If so, the robe is no longer "only" a replica, it is as essential as the second part of a tally. Thus, the importance of the robe in Chan imagination goes far beyond that of a simple symbol of transmission. ${ }^{20}$ It constitutes the Buddhist equivalent of a dynastic treasure (bao 筫). Anna Seidel has argued that the Chan tradition, like the imperial and Taoist traditions, felt the need for a visible expression of its legitimacy in sacred objects (bao): thus, while the Hetu 河圖 (River Chart) and the Luoshu 洛書 (Writing of the River Luo), diagrammatic talismans of supernatural origin, came to symbolize Chinese sovereignty, and the registers [lu 䈄] expressed the authority of Taoist priests, the monastic robe warranted the authenticity of the Chan Dharma transmitted in an uninterrupted line since the time of the Buddha.

In a seminal essay, Max Kaltenmark showed that "between the sacred jewels (pao), dynastic or family talismans, and magical charms $(f u)$ there was no difference in substance but maybe at the most a difference of degree, all in all proportional to the prestige of their owners-whether a king, noble, or simple magician." 21 These sacra were thus perceived as a token of good fortune, a guarantee of life and power, and a proof of the Celestial Mandate.

The same model operated in the Chan transmission ritual. We know since Kaltenmark that the weight of dynastic treasures is a function of the virtue of their possessors. ${ }^{22}$ The Dharma robe and the Dharma itself are complementary, interdependent, forming a single bipartite reality, a $f u$. By metonymy we come to the idea that there really is an identity between the robe and the Dharma. As a consequence, those who wear the Buddhist kāsāya, the Dharma robe, become ipso facto Buddhas. ${ }^{23}$ We can see to what point the symbolism of the Dharma robe, a robe which was so heavy that Huineng's rival could not even lift it when he tried to steal it, grows out of these ideas. ${ }^{24}$

1" See Jacques Gernet, "Biographie du Maître Chen-houei du Ho-tsö," Journal Asiatique 239 (1951): 46, n. 3.

${ }^{20}$ On this question, see Bernard Faure, Visions of Power: Imagining Medieval Japanese Buddhism, Princeton: Princeton University Press (forthcoming).

${ }^{21}$ See Max Kaltenmark, "Ling-pao: Note sur un terme du taoïsme religieux." in Mélanges publiés par l'Institut des Hautes Etudes Chinoises, Paris: Presses Universitaires de France, vol. 1 (1960): 559-588; on the use of talismans in Taoism, see also: Isabelle Robinet, Taoist Meditation: The Mao shan Tradition of Great Purity, transl. Julian Pas and Norman Girardot. Albany: S.U.N.Y. Press, 1993; and John Lagerwey, Taoist Ritual in Chinese Society and History. New York: Macmillan. 1987: 155-161.

${ }^{22}$ See Anna Seidel, "Dynastic Treasures and Taoist Sacraments." 1983.

2.3 See Ishikawa Rikizan, op. cit., 102-152.

24 The motif of the kassaya's weight is also found in the biography of Bodhidharma's contemporary, the dhyāna master Sengchou 僧椆. When Emperor Xuan Di 宣帝 (r. 550-559) wants to see a Buddhist wonder, Sengchou throws his käsäya to the ground. The emperor 
The Chan kāsayya must therefore be understood as a dynastic treasure. In the imperial edict accompanying the restitution of robe and bowl to Baolinsi 寶林寺, the kāsăya was indeed called "treasure of the State" [guobao 國寶]. Even if one doubts the authenticity of this edict, the fact remains that the Southern school tried

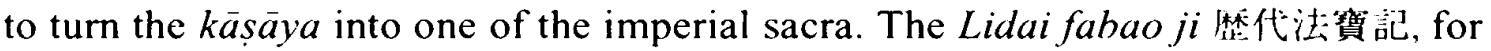
instance compares the transmission of the robe to the abhiseka ritual performed for the consecration of a cakravartin king, and thus insists on the Indian precedent. But the Buddhist influence is in the choice of the robe itself, which never appears among Chinese treasures. After the interruption of the transmission of the robe, the proof resides in the possession of sacred texts - a kind of return to Taoism. From the ninth century onward, as a proof or token, the robe is challenged by verses and texts. Other objects are used concurrently, such as relics (bodily relics, sarira, or relics of contact: hossu 拂子, shujō 拉杖, etc.) and portraits (chinsō 頂相). However, a ritual of transmission of the robe was elaborated during the Song: ${ }^{25}$ still today, in Chinese and Japanese Buddhism, ordination as well as Dharma transmission includes the transmission of a kạsăya. ${ }^{26}$ As we will see, the robe and other "tokens," which were at first included as proofs of enlightenment, tended to become its magical cause.

\section{Dōgen's symbolic elaboration}

Despite Huineng's alleged interruption, the transmission of the robe - along with that of other insignia - remained an essential part of the Dharma transmission. We are told for instance that Dainichi Nōnin 大日能忍, the founder of the Darumashū 達 摩宗, received in 1189 a portrait of Bodhidharma, a portrait [chinsō] of the Chinese master Zhuoan Deguang 拙庵徳光 (1121-1203), and his Dharma robe [hoe 法衣]. Dōgen also received various insignia from his master Rujing (1162-1227)-among them a robe of a blue-black colour-like that of Bodhidharma and of the Indian patriarchs - transmitted since Fuyong Daokai 芙蓉道楷 (1043-1118). ${ }^{27}$ However, it is with Doggen that the robe came to acquire a symbolic surplus that would eventually and paradoxically undermine its function as a sign of transmission.

orders several of his men to pick it up, but they fail to move it. Then Sengchou has it lifted effortlessly by a novice. See Busso kesa kō 佛柤袈装考, ZSZ Shingi, 539.

${ }^{25}$ See Shoufayi 受法衣, T. 48, 2025: 1122 b.

${ }^{26}$ See Holmes Welch, The Practice of Chinese Buddhism 1900-1950, Cambridge Mass.: Harvard University Press, 1965: 156-157, 290; Zengaku daijiten 禪学大辞典, Tōkyō: Taishūkan 大修館, 1978: 887c.

${ }^{27}$ See Ōkubo Dōshū 大久保道舟, Shūtei zōho Dōgen zenji den no kenkyū 修定增補道元禪 師伝の研究, Tōkyō: Chikuma shobō 筑摩書房, 1971：169-171; and Shakushi hōe kun, ZSZ, Shingi, 553a. 
In the later Sōto tradition, several texts deal specifically with the kesa. ${ }^{23}$ They all derive from two chapters of Dōgen's Shōbōgenzō 正法眼藏 (T. 2582), “Den'e 傳衣” (Transmitting the Robe) and “Kesa kudoku 袈裟功徳” (Merits of the kāsāya). ${ }^{29}$ From the title of the two chapters, it would seem that "Den'e" is concerned primarily with the mythmaking of the robe transmission, while "Kesa Kudoku" dwells on the magical properties of the robe itself. ${ }^{30}$ Actually, most of the material is repeated verbatim in both texts, and it has been suggested that "Den' $e$ " was merely a draft for "Kesa kudoku." In these chapters, Dōgen first recapitulates the transmission of the robe through the twenty-eight Indian and six Chinese patriarchs. ${ }^{31} \mathrm{He}$ then proceeds to explain the virtues of the kāsajya, the correct way to wear it, to preserve it, the materials used to make it, the various kinds of robes, and the ten virtues of the kâsāya.

Dōgen constantly underscores that the transmission of the kāsāya means the only true transmission of the Dharma. He explicitly compares the transmission of the Dharma to the investiture of a prince, and the kāsanya to the imperial regalia. He emphasizes that several Tang emperors-Zhongzong 中宗 (r. 683-684 and 705-710), Suzong 肅宗 (r. 756-762) and Daizong 代宗 (r. 762-779)-had asked that it be sent to court and venerated it as a dynastic treasure. Doggen also insists on the fact that this transmission is a characteristic of Chan: "Collateral lineages did not transmit the Buddha's kāsāya." 32

After quoting the imperial letter in which Daizong calls the robe a "dynastic treasure," Dōgen admits reluctantly that Japanese dynastic treasures are more ancient than the robe of the Buddha. ${ }^{33}$ But he argues that the latter is nevertheless superior because it has been transmitted in a direct line, whereas the Japanese regalia were transmitted neither in a direct line, nor in an orthodox succession. However, as Anna Seidel remarked, what Dōgen transmits is only the belief in the $k a \bar{s} a \bar{y} a$ through the orthodox rules for its construction, its use and its symbolic role in the Dharma transmission-since the robe itself has remained at Caoxi. It is this that Dōgen chooses to exalt, over that of the three regalia (mirror, sword, and jewel)

${ }^{28}$ Busso kesa kō, in ZSZ, Shingi, 2: 524-547; Hōfuku kakushō 法服格正, comp. by Mokushitsu 黙公 (1775-1833), ibid., 639-676; Den'e zōbi shōhaka 傳衣象章章巴歌, ibid., 600-637; Shakushi hōe kun, ihid., 549-575; Hōfuku shōgi shaku 法服正儀釋, ibid., 577-599.

${ }^{29}$ See “Kesa kudoku," T. 82, 2582: 47c-56a, Dögen Zenji zenshü 道元禅師全集 [DZZ] 1: 623-645; “Den'e," T. 82, 2582: 56a-62a, DZZ 1: 285-300.

30 See "Kesa kudoku" in Yūhō Yokoi, Zen Master Dōgen, New York and Tōkyō: Weatherhill, 1976: 88-106.

${ }^{31}$ See "Kesa kudoku," in T. 82, 2582: 47c4, 48c22, 56a21.

${ }^{32}$ T. 82, 2582: 48a2

33 See "Den'e," T. 82, 2582: 53c-54a. On this question, see also Faure, "Alternative Images of Pilgrimage: Sung-shan and Ts'ao-hsi," in Susan Naquin and Chün-fang Yü, eds., Pilgrimage and Sacred Sites in China, Berkeley: University of California Press, 1991: 150-189. 
of the Japanese emperor. ${ }^{34}$ After Huineng, the patriarchal robe is no longer transmitted, and monks sew, wear and transmit their own kāsajya; but-and this is for Dōgen the crucial point-they do so according to instructions also correctly transmitted since the Buddha.

Dōgen distinguishes two incorrect forms of transmission: in the first, a kāsāya is transmitted, but not in a correct fashion-as in the transmission from Buddhabhadra (359-429) to Sengzhao 僧肇 (d. 414); in the second case, only the Dharma is transmitted, without the kassayya-as in the transmission that allegedly took place between the fourth Chan patriarch Daoxin 道信 (580-651) and Niutou Farong 午頭 法融 (594-657). ${ }^{35}$ "Correct transmission," for Dōgen, refers to two different things: the kāsāya of the Buddha itself, and the method for making a kāsāya like that of the Buddha. Dōgen conveniently collapses the two meanings. He seems to confuse, or at least to conveniently shift between, the kāsāya of transmission and the kāsayya of ordination, attributing to the latter all the talismanic virtues of the former. However, it is no longer, at the time, a particular robe, but rather the transmission of the correct rules for the creation and maintenance of monastic cloth-rules that he has received and now transmits. Paradoxically, by focussing on the symbolism of the robe, Dōgen contributed to emptying it of its meaning as the "robe of Dharma transmission" (dembo-e). From that moment onward, and largely because of him, other artifacts become essential in the transmission, namely the lineage chart (kechimyaku 血脈) and the transmission certificate (shisho 翤書). Compared to these documents, the robe seems to have played a minor role in the later Sōto transmission-although its symbolic function becomes increasingly conspicuous. ${ }^{36}$

The kāsāya becomes the magical "robe of deliverance" (gedatsufuku 解脱服), and the ordination is the magical ritual that effects this deliverance. Thus, in an interesting rhetorical move, Dōgen collapses the two independent traditions regarding the kāsāya: the Vinaya tradition(s) of Daoxuan 道宣 (596-667) and Yijing 義浄 (635-713), dealing with the kāsāya as monastic cloth, and the Chan tradition dealing with the kâsăya as symbol of transmission. By the same "token," he shifts from the unique kāsāya to its "orthodox" replicas, attributing to the latter all the powers of the original model kept by Huineng and his disciples. From that moment onward, the transmission has actually become a dissemination. It becomes more difficult to argue, as Dōgen does: "All the disciples of Caoxi's old Buddha [Huineng] transmitted and preserved the tradition of the Buddha's kāssāya. Monks from other [schools] could not match this." ${ }^{37}$ However, Dōgen remains adamant that

\footnotetext{
${ }^{34}$ T. 82, 2582: 56b-c.

${ }^{35}$ Ibid., 48a.

36 On the problem of Dharma transmission in the Sōto sect during the Edo period, see William Bodiford, "Dharma Transmission in Sōtō Zen: Manzan Dōhaku's Reform Movement," Monumenta Nipponica 46, 4 (1991): 423-452.

${ }^{37}$ T. 82, 2582: $53 \mathrm{a} 57$.
} 
other robes, for instance those devised in the Vinaya school, are utterly nonorthodox and consequently inefficient, unable to bring about awakening. ${ }^{38}$ Dōgen is able to do this by applying to the rituals of transmission and of ordination a similar "hermeneutic of transcendence."

\section{Silk or cotton?}

We have seen how, in Tang China, the monastic robe, borrowing elements from the Indian tradition of the abhiseka, or royal unction, but also from the Taoist and imperial traditions, came to assume a new symbolic value, a value that supplemented and eventually contradicted its practical function. In Japan, first within esoteric Buddhism, then with Dōgen and his successors, this process of symbolic superscription resulted in an "absolutization" of the kāsāya that led to assert the kingly status of the monk over his ascetic practice. This evolution went hand in hand with, or was perhaps permitted by, a change in conceptions regarding the material of the kasâya: cotton was gradually superseded by silk, which became a more convenient symbol-despite certain negative connotations to which we will return--to signify the eminent dignity of the monks. Later on, in the Edo period, the reassertion of the early Buddhist ideal of austerity will be marked by a return to simpler materials like hemp and linen.

With Dōgen, the kāsăya becomes an absolute, transcending all dualistic categories: “A kāsāya is not something 'made' or 'non-made', 'localized' or 'unlocalized': it is the ultimate realization transmitted from a Buddha to another." ${ }^{39}$ According to him, although the materials for making a kāsãya may be either silk or cotton, it is essential not to discriminate between them. Dōgen quotes the following Chan dialogue (mondō 䦚答): “Was the kāsāya transmitted in the middle of the night on Mt. Huangmei 黄梅 Ul made of cotton, silk, or satin?" Huineng's answer: "Neither cotton, nor silk, nor satin." ${ }^{40}$ Although Dōgen himself does not draw as directly on esoteric symbolism as his successors will, he clearly opens the door to this hermeneutic proliferation: "You should carefully study whether the material, the color, and the size of the kāsayyas of all the Buddhas are finite or infinite, with form or formless." +1

Likewise, in "Hatsuu 鉢歪," Dōgen writes that the patriarchal lineage is no other than "The Treasure of the True Dharma Eye, the Wondrous Mind of Nirvanna, the käsayya and the bowl." And he adds: "Those who have not penetrated the mysteries of the Buddhas and Patriarchs say, 'The Buddha's kāsāya is made of silk or cotton, and silk is woven of silk thread,' or 'The Buddha's bowl is made of stone, earthenware, or iron.' Such words show that they have no eye for the study [of the

\footnotetext{
${ }^{38}$ Ihid. $49 \mathrm{~b}$.

${ }^{39}$ Ihid., $49 \mathrm{c}$.

${ }^{40}$ Sec "Den'e," ibid., 61 a9.

${ }^{41}$ Ihid. $50 \mathrm{c} 26$.
} 
Way]. The Buddha's robe is simply the Buddha's robe, and we must not see it as being made from silk or cotton. Such views are obsolete. The Buddha's bowl is simply the Buddha's bowl, and we must not say that it is made of stone or earthenware, iron or wood." 42

Despite his appeal to the Mahāyāna orthodoxy of non-duality, Dōgen is embarrassed to explain the radical evolution that led from tattered garments to fine silk. Instead of suggesting the coexistence of two distinct kăsāya of the Buddha, one made of discarded, tattered cloth (funzōe), worn during (or symbolizing) the practice of austerities (dhüta-guna), another of golden brocade (sōgari-e) representing the eminent dignity of the enlightened master, Dōgen attempts to justify rationally the shift from the funzo-e to the sogari-e.

As mentioned earlier, the ideal fabric for a kāsâya was cloth discarded by men and women because of its impurity. Dōgen, according to the Vinaya tradition, describes four of the ten types of discarded cloth that can serve to make a robe: cloth chewed by oxen, gnawed by mice, burned by fire, soiled by menstrual blood, soiled by blood from childbirth, discarded at shrines, discarded in a cemetery, presented as offering, discarded by government officials, used to cover the dead. After having been picked up, however, they become the cleanest materials for making a kâsâaya ${ }^{43}$ This purification process (through dyeing) serves as a metaphor for the way in which the practitioner tries to sort out his passions. The motif of dirt and impurity, although ultimately negated, is particularly significant here. Inherited from early Buddhist asceticism, this motif remained powerful as a marker of transcendence. We see it reappear in one of Keizan's dreams: "I owned an old robe that I had not put on for a long time. I now wanted to wear it, but when I found it, rats had made their nest in it and it was spotted with filth that looked like cow and horse excrement, hairs from horses' tails, and human hairs. I brushed it off, and then, after I had cleaned it, I put it on. It was truly a strange dream, an auspicious dream." 44 We will return later to the relation between defilement, and more precisely blood pollution, and the kāsāya.

In principle, Dōgen subscribed to this ascetic ideal, and he insists that "Practitioners... should not wear fashionable clothes." 45 According to Ejō's 懐壯 Shōbōgenzō zuimonki 此法眼藏随聞記, he once said: “Laymen say it is good to wear luxurious silks, embroidered garments, and brocades. But in Buddhism it is the opposite: tattered robes are good and pure; richly embroidered garments are evil and soiled." 46 However, he was confronted with a singular problem: "In today's Japan,

${ }^{42}$ See "Hatsuu," ibid., 260a2, b7-14.

4.3 T. 82, 2582: $50 \mathrm{~b}$.

${ }^{44}$ Jōsai Daishi Zenshū 常濟大師全集 [JDZ]. ed. Kohō Chisan 孤峰智㻧, 433; on Keizan's dreams, see Faure, Visions of Power, ch. 5.

45 "Kesa kudoku," T. 82, 2582: 53a12.

${ }^{46}$ See Masunaga Reihō. A Primer of Sōtō Zen: A Translation of Dōgen's Shōbōgenzō Zuimonki. Honolulu: University of Hawaii Press, 1975: 71. See also ibid., 79. 
there are no such discarded materials. Even when one looks for them, one cannot find any. How sad, to live in such a small peripheral country! Therefore, we have to use the pure materials given to us by donors, or by men and devas. Such discarded materials are neither made of silk nor of cotton; they are not made of gold, silver, pearls, jewels, crepe, muslin, brocade, or embroidery. They are merely discarded materials." 47

In a Japanese variant of what we could call the "rhetoric of Marie-Antoinette," 48 Dōgen writes: "When fine cotton is not available, crepe or muslin may be used."49 Admittedly, in China as in Japan, cotton was a rarer material than silk. Nevertheless, for all his will to orthodoxy, Dōgen seems unwilling to admit that the canonical robe was made of cotton. ${ }^{50}$ For instance, the robe transmitted to the Chan master Jingjue 淨鼠 (683-ca 750) by his master Xuanze 玄朢 (d. 708), a co-disciple of Huineng, was in cotton, and so was, according to the Caoxi dashi biezhuan 曹渓大師別傳, that of Huineng himself (with, however, a lining in green silk). ${ }^{51}$

Dōgen's logic of "if you have no cotton, use silk" may strike a critical reader as rather disingenuous. He pushes it one step further (or undermines it) by resorting to the Mahāyāna tenet of non-duality: "Among the discarded materials you picked up, there may be silk looking like cotton, or cotton resembling silk, but when you use it, you should not call it silk or cotton, but simply 'discarded material.' Because it has been discarded, it is neither silk nor cotton." 52 Only narrow-minded Vinaya masters could pretend to distinguish between moral good and evil in these matters, unable as they are to take the high metaphysical ground.

The ideological implications of Dōgen's "absolutist" position become clear when he frontally addresses the traditional objection against the use of silk. The problem of killing life has worried many Buddhists, particularly in the Vinaya school. But Dōgen dismisses their simplistic notions of good and evil: "Cotton is not necessarily pure, nor is silk necessarily impure." His argument runs as follows: "If we dislike silk, we must also dislike cotton. Why is that? We dislike the fact that the production of the silk thread entails the killing of life. This is truly laughable! Is not cotton also obtained at the expense of living things? This sentimental distinction between animate and inanimate beings is not yet free from common feelings. How could you thus understand the Buddha's kāsāya?" 53

${ }^{47}$ T. $82,2582: 55 \mathrm{~b} 7$.

${ }^{48}$ To the complaints of the French people about the shortage of bread, the Queen of France Marie-Antoinette supposedly said, "S'ils n'ont pas de pain, qu'ils mangent de la brioche!" ["If they have no bread, let them eat brioche!"]

${ }^{49}$ T. 82, 2582: 52c-53a.

50 "According to an old tradition," says Mujaku, "Bodhidharma's Dharma robe was made of cotton." See Zenrin shokisen. 684b.

I $Z Z$ 146: 484a-b.

52 T. 82, 2582: 60b15-20.

${ }^{53}$ See "Den'e," ibid., 60b4-9. 
Actually, Dōgen is taking his cues from the Vinaya master Yijing (without referring to him). According to Yijing, the Indian Vinaya, and consequently the Buddha himself, did not prohibit the use of silk. Therefore, "What is the use of laying down rules for a strict prohibition of silk?... Why should we reject the silk that is easy to be obtained, and seek the fine linen that is difficult to be procured?.... But if [the refusal of the use of silk] comes from the highest motive of pity, because silk is manufactured by injuring life, it is quite reasonable that they should avoid to use of silk to exercise compassion on animate beings. Let it be so; the cloth one wears, and the food one eats, mostly come from an injury to life. The earthworms [that one may tread while walking] are never thought of; why should the silkworm alone be looked after? If one attempts to protect every being, there will be no means of maintaining oneself, and one has to give up life without reason. A proper consideration shows us that such a practice is not right." 54 After rejecting the extremist ahimsā, as practised by Jains, Yijing compares the use of silk to the appropriate eating of meat (received as a gift, without intention of killing). Thus, although a monk is not allowed to beg personally for cocoons containing silkworms, or to witness the killing of the larvae, he is allowed to accept silk as a gift. Yijing therefore opposes the "strange idea" of those Vinaya masters who reject silk in favor of linen for their kāsa àya. ${ }^{55}$

Having cleared the way (or so he believes), Dōgen can now emphasize the magical efficacy of the kāsāya: "Not only have we been able to encounter the Buddha Dharma which is difficult to encounter, but now, as Dharma-heirs to the true transmission of the Buddha's kāsāya, we have seen and heard this, and studied it. It means that we have seen the Tathāgata, we have heard him preach the Dharma, we have been illuminated by his light, we have experienced his samädhi, we have directly received his mind, and obtained his marrow. We actually are covered with the kāsāya of the Buddha Śăkyamuni, and Śăkyamumi Buddha actually gave us his kāsāya." \$6 To explain these powers, Dōgen tells of the fundamental vow made by the Buddha when he was still a Bodhisattva. This vow accounts for the merits of the $k \bar{a} s \underline{a} y a$, its capacity to bring abundant benefits to all sentient beings: "Those advantages are those of the kāsāya itself, they do not derive from the practitioner's arduous and constant practice." 57

Thus, although the robe worn by monks is not the original one, it is its true replica, its double. Dōgen makes clear that it is more than a symbol in the ordinary sense, and that it should be worshipped as an icon, a double of the Buddha. He emphasizes the magical powers of the "deliverance robe," which allows those who

\footnotetext{
${ }^{54}$ See I-tsing [Yijing], A Record of the Buddhist Religion, 58.

${ }^{55}$ Ibid., 60.

${ }^{56}$ T. 82, 2582: $51 \mathrm{a8}-18$.

57 Ibid., 54c 19-21.
} 
wear it to overcome karmic bondage. The miraculous power of a kāsāya is "beyond comprehension," and its merits "inconceivable": no one, past or present, has ever realized enlightenment without wearing one. ${ }^{58}$ Thus, the kașaya allows one to "reach the highest rank," to obtain awakening or, as Dōgen puts it, to "quickly realize the body of the Dharma-king." "59 The kāsayya itself, is "[one of] the bodily marks of all the Buddhas." "ro

The transcendental redefinition of the robe eventually affects its physical characteristics: after enumerating the nine kinds of samghat $\bar{t}$ (from nine to twentyfive strips), Dōgen adds a kāṣayya of 250 strips and another of 84,000 strips. ${ }^{61}$ The figure 84,000 , purely symbolic, represents the Dharma, the totality of the Buddha's teaching as recorded in the sutras, whereas the number 250 is that of the rules of the pratimoksa, the monastic list of precepts edicted by the Buddha in the Vinaya. The $k \bar{a}$ șàya becomes for Dōgen the shōboggenzō itself, the much-vaunted "treasury of the eye of the true Dharma": "Those patriarchs who have correctly transmitted the shōbōgenzō have inevitably transmitted this kāssāya." The kāsăya is even in some respects superior to the Dharma: "To hear a word or a verse of the Dharma can be achieved through the intermediary of trees or stones, and this hearing is not limited to the nine ways. But the merits of the direct transmission of the kāsāya are hard to encounter in the ten directions." ${ }^{2}$

The virtue attributed to the kâsăya as a symbol of transmission finally extends to the kassayya received at the time of ordination. In the later Sōto tradition, the moment of ordination collapses with those of enlightenment and of Dharma transmission. Ordination, conferring automatic deliverance through a ritual affiliation with the lineage of the Buddha, takes precedence-logical as well as chronological-over enlightenment and transmission. ${ }^{63}$ Already with Dōgen, the kāsăya, as symbol of ordination, partakes of all the magical virtues of ordination. ${ }^{64}$ The relation between the ordination ritual and the ultimate deliverance is well expressed in the "Kăsayagātha" quoted by Dōgen: "How wonderful this deliverance robe!/ Like a formless field of merits/ It expounds the Tathāgata's teaching/ And saves all sentient beings." 65

58 Ibid., 54c.

${ }^{59}$ Ibid., $54 \mathrm{c} 23$.

${ }^{60}$ Ibid., $58 \mathrm{~b} 25$.

${ }^{61}$ Ihid., $58 \mathrm{a}$.

62 Ibid., $55 \mathrm{c} 23$.

${ }^{63}$ See Bodiford, Sōtō Zen in Medieval Japan, Honolulu: University of Hawaii Press, 1993: 163-184; and Faure, Visions of Power, chapter 2.

${ }^{64}$ In the $D Z Z$ edition, the "Kesa kudoku" chapter follows the "Shukke kudoku" ["The Merits of ordination"] chapter. See also Yokoi, Zen Master Doggen, 69-83 and 88-106. In the Taishō edition, however, it precedes "Den'e."

${ }^{65}$ T. 82, 2582: 54a24-25. 
In “Jukai 受城," Dōgen insists that “if one borrows someone else's robe and bowl, even though one ascends the ordination platform to receive the precepts, one will not obtain them." If one does, one cannot truly be said to have received the precepts, and one receives no benefit from the ordination. ${ }^{66}$ However, he argues elsewhere that "a [kāṣāya] made newly and independently by every monk is not correctly transmitted, and this monk is not a true heir [of the Buddha]." ${ }^{67}$

As the story of the nun Utpalavarnā shows, the käsäya works miracles, even if it is worn as a joke. Utpalavarnā was in a former life a courtesan, who, having once put on a monastic robe as a jest, was later able, due to the good karmic impregnation of this act, to enter the Buddhist path. ${ }^{68}$ The merits of wearing a $k \bar{a} s \bar{y} y a$, and consequently the merits of ordination, are such that they outweigh any negative karma. As Utpalavarnā, trying to convert other women, puts it: "Therefore I know that once you leave the family to receive the precepts, even though you may break those precepts, owing to them you will reach Arhathood." 69

Although it is the defining characteristic of the cleric, the kāsa ya can also be conferred to lay adepts, along with the Bodhisattva Precepts: "The fact that men and devas, although they are lay disciples, have received and preserved the kāsayya, is one of the utmost mysteries of the Great Vehicle," writes Dōgen, who gives as examples the Chinese emperors Liang Wudi 梁武耍 (r. 502-549), Sui Yangdi 隋煬帝

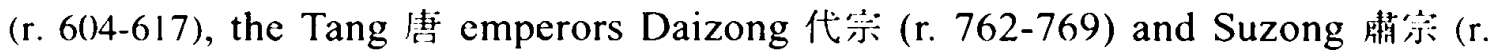
756-762), and more important for his purpose, the Japanese ruler Shōtoku Taishi 㘶 德太f· (574-622). Dōgen concludes, “Thus, whether emperor or retainer, one should without delay receive and preserve the kāsayya, and receive the Bodhisattva Precepts." 70 Thus, anticipating a trend that will become dominant in later Sōtō, Dōgen advocates the ordination of all creatures great and small, kings and prostitutes, slaves, heavenly beings and animals. ${ }^{71}$ Several later Sōtō texts regarding the kạsayya insist on the role it came to play in converting local gods. An illustration is found in the legend of the Rinzai master Muhon Kakushin 無本営心 (1207-1298). While he was standing on the famous "rock-bridge" of Tiantai shan Fílll in China, the Bodhisattva Mañjuśri appeared to him in the form of a young boy and gave him a kāșāya. After Kakushin returned to Japan, as he was visiting a shrine one day, the kami, through the intermediary of a miko 시, asked to be ordained and to receive the robe. Kakushin gave the robe to the miko, and it became one of the treasures of the shrine. Later on, a kami appeared to the Sōtō Zen master Daikū Genko 大筀玄虎 (1428-1505), founder of Jōgenji 淨眼寺, and,

\footnotetext{
66 Ihid., 306c.

67 "Den'e," ibid., 58al-2.

68 "Kesa kudoku," ibid., 52a-b.

${ }^{69} \mathrm{Ibid}$., 52b7-8.

${ }^{70}$ Ibid., 53cl7-54a9.

71 "Den'e," ibid., 62a.
} 
after receiving the Precepts from him, gave him the robe. ${ }^{22}$ The text insists that Kakushin, although he was a Rinzai master, had himself received the Precepts (and therefore the ordination robe) from Dōgen.

The powers of the kassaya should therefore be put in relation with the magical use of the ordination ritual, and the talismanic function of the kechimyaku, in particular during situations of crisis and for the rite of postmortem ordination.

We have seen with Dōgen the emergence of hermeneutic tendencies that were played out in the later Sōto tradition, in particular in the kirigami: an absolutization of the kassāya, reinterpreting all its concrete characteristics in higher, metaphysical terms. This abstraction leads paradoxically to a kind of commodification: the $k a \bar{s} a \bar{y} a$ is no longer a unique physical robe, transmitted from generation to generation by a patriarch to his successor-as in Shenhui's theory, rendered useless by the historical evolution of the Chan school (from one single line to "Five Houses"); it has now become a ritually reproducible object. However, this multiplication by no means diminishes its aura, as it does, according to Walter Benjamin, in the case of a work of art: the replicas of the robe preserve all the virtues and magical powers of the original which are that of the Buddha himself. ${ }^{73}$

\section{The ritual symbolism of the kirigami}

From the fourteenth century onward, the Sōtō school spread throughout Japan, becoming an essential part of the popular religious landscape. Most Japanese scholars explain this success as the cause (and/or effect) of the "mikkyō-ization" of Sōtō Zen, a process that becomes particularly obvious after the Muromachi period in the kirigami-a type of documents whose diagrammatic aspect and ritual function bring to mind the prophetic scriptures (chanwei 䜟緯) of Confucian imperial ideology and the Taoist talismans studied by Anna Seidel. Before turning to these documents, a few words about Keizan may be in order, since he is usually held responsible for this evolution that supposedly contaminated Dōgen's "pure Zen."

As noted earlier, in his Denkōroku 傳光録, Keizan explains the origin of the kāsāya. He also tells about the Buddha's transmission to Kāśyapa, but the real recipient is Maitreya. For him, the robe is clearly a kind of sarira. Keizan also indicates that a robe was transmitted from Kāśyapa to Ānanda, but, as we have seen, he distinguishes between various kinds of kāsa àya. We possess an autograph text from Keizan on the transmission of the robe: Hōe sōdensho 法衣相傳書. ${ }^{74}$ In

\footnotetext{
${ }^{72}$ See Shakushi hōe kun, ZSZ Shingi, 573, and Hōfuku kakushō, ibid., 641-642.

${ }^{73}$ On this question, see Walter Benjamin, "The Work of Art in the Age of Mechanical Reproduction," in Benjamin, Illuminations, New York: Schocken Books, 1968.

${ }^{74} J D Z, 489$.
} 
Keizan's Denkōroku, the kāsāya is also the magical proof that the Dharma of the patriarch Simhabhikșu has been duly transmitted. On the whole, Keizan seems to simply follow Dōgen, and he cannot be held responsible for the hermeneutic proliferation that was to find one of its major expressions in the Sōto kirigami.

In the medieval Zen tradition, the process of symbolic superscription affects all the personal possessions that will become ritual insignia-the bowl, the staff (khakkhara, J. shakujo 錫丈), the fly-whisk (hossu 拂子), etc. ${ }^{75}$ In China, the robe and the bowl went hand in hand, and from hand to hand, as can be seen in the Fozhi biqiu liuwu tu 佛制比丘兵物圖 (T. 1900). Despite Shenhui's emphasis on the robe as the only token of transmission, it seems that other objects have always be transmitted. In the epitaph of the Northern Chan monk Jingjue, for instance, we are told that he had received from his master Xuanze a cotton kāsāya, a water jug, a bowl, and a staff. ${ }^{76}$ The joint transmission continued long after Shenhui, as can be seen from the title of a Sōto kirigami dealing with the "Method for transmitting the robe, bowl, and lineage chart"(Ehatsu kechimyaku denju sahō 衣鉢血脈傳授作法). ${ }^{77}$

The begging bowl was also particularly important as a token of transmission. In many Chan chronicles, the robe and the bowl are mentioned together, as if they constituted another kind of bipartite symbol. ${ }^{78}$ The bowl's spherical shape symbolizes the mind, the true form of the Buddha Sākyamuni. Like the robe, it is guarded by four protective gods, and thus actualized the center and the four cardinal points. ${ }^{79}$ In the Keiran shūyōshu 渓嵐拾葉集 $(T .2410)$, a fourteenthcentury Tendai encyclopedia, the robe is described as complementary, yet superior to the bowl. When someone asks about the meaning of the statement, "The robe expresses the spiritual essence, while the bowl expresses the doctrinal method," the master replies that this statement reveals the difference between esoteric and exoteric Buddhism. ${ }^{80}$

Perhaps the most striking feature of the kāsāya is its fragmented surface: the robe is divided vertically and horizontally by stitches, cords, folds, and painted lines, in a checkered pattern or a patchwork. This fragmented surface may symbolize the realm of samsära, the world of multiplicity, a cosmological structure of numbers and symbols - and at the same time a way out of it. As we will see later, a similar

\footnotetext{
${ }^{75}$ See Faure, Visions of Power, ch. 8.

${ }^{76}$ See Yanagida Seizan 柳田聖山, Shoki zenshū shisho no kenkyū 初期禪宗史書の研究, Kyōto: Hōzōkan 法蔵館, 1967: 597.

77 See Ishikawa, op. cit. (6): 109. We may note in passing that Shenhui's grave, recently discovered at Longmen 龍門, contained a bowl and various other ritual implements, but no kāsāaya.

${ }^{78}$ T. 76, 2410: 768b.

${ }^{79}$ Ehatsu kechimyaku denju sahō. See Ishikawa, op. cit. (6): 114-115. See also Shōbögenzō, "Hatsuu," in DZZ 1: 565.

${ }^{80}$ T. 76, 2410: 768b.
} 
symbolism was applied to the stūpa. Paradoxically, as the above quotation from the Keiran shūyōsh $\bar{u}$ indicates, the kāssayya is also seen as an expression of the absolute, formless realm: hence its designation as "formless robe" (musō-e 無相衣).

\section{Numbers and colours}

The most basic symbolism is numerological. Already in esoteric Buddhism, the three robes correspond to various threefold rubrics: three Vehicles, three bodies of the Buddha, etc. ${ }^{81}$ We have also seen that the strips are always in odd numbers-from five to twenty-five, including all the intermediary numbers. This characteristic may have simply to do with the symmetrical structure of the kassāya, divided by a middle strip. But purely numerological factors have played a part-in China, the odd numbers (except five, symbolizing earth and the center) are seen as representative of Yang, the male emblem. However, the square parts (the shiten 四天 or kakuchō at the four corners, representing the four Guardian Kings, the niten二天 at the upper part of the kāsāya, representing the two Benevolent Kings) are even in number. According to the Fukuden-e kirigami 福田衣切紙, a document allegedly transmitted secretly by Dōgen at Eiheiji 永平寺, the five-strip robe is worn during peregrination (angya 行脚), the seven-strip robe is worn during meals, the nine-strip robe is worn for sermons, while the twenty-five-strip robe is the robe that the Buddha, at the time of passing into Nirvāna, transmitted to Ānanda (not Kāśyapa). ${ }^{82}$ Another passage of the same kirigami gives the following details: "The twenty-five strips are divided into nine, seven, five, three, and one. The nine-strip robe is the robe of predication, the seven-strip is the robe for meals, the five-strip robe is for going in the streets of capital, the three-strip robe serves as a sitting-mat (zagu 坐 具), the one-strip kesa serves as a bag for the bowl. All these add up to twenty-five strips." 83 The symbolism of the strips is further complicated by the horizontal divisions that form a contrast, on each strip, of one short and several long pieces. ${ }^{84}$

According to the Fozhi biqiu liuwu tu, a Vinaya commentary rather critical of the Chan tradition, Chan monks usually wear a nine-strip robe: "At times they [i.e., Chan monks] have three long patches [on each strip of their kāșāya], at times four;

81 In the Tendai tradition, for instance, the three robes (five, seven, and nine strips) correspond to the three inspections (kan 觀, Sk. vipasyanā) of the provisional [ke 假], emptiness $[k \bar{u}$ 空], and the middle way [chüdo 中道], respectively. They also correspond to the Taizōkai 胎蔵界, Kongōkai 金剛界, and Susiddhi (J. sojitsuji 蘇悉地) mandalas, to the three letters of the mantra aum, and to the nirmanna-, sambhoga- and dharma-kâya. See Keiran shūyōshū, T. 76, 2410: 768c.

${ }^{82}$ See Ishikawa, op. cit. (6): 106.

${ }^{83}$ Ibid., 108.

${ }^{84}$ See for instance the Ehatsu kechimyaku denju saho, quoted infra ["The robe as womb"], according to which the length of the pieces expresses the phases of the gestation process. 
they fabricate them as they like, not according to the Dharma." 85 The number of strips of the samghati $\bar{c}$ also indicates the rank of the priest who wears it. The dimensions of the kassayya are sometimes measured in relation to certain parts of the body of the person who will wear it. ${ }^{86}$ In this sense, there is truly a metonymic identity between the man or woman and his or her robe.

The colour symbolism too is obviously important, as the kāsăya derives its name from its colour: originally said to be the colour of flesh (nikushiki 肉绝), the robe must not be in pure, primary colours, but in "mixed" or "impure" colors (fushōshiki 不正色) ${ }^{87}$ Paradoxically, the fact of dyeing a piece of cloth in an "impure" colour was seen as a purification-probably because it imposed a unified colour that covered all the multiplicity of shades and stains; but also because what appear as "pure" colours to profane eyes are not so from a higher viewpoint. One of the reasons invoked for this was to distinguish the monastic robe from lay robes, which were usually white, or in other primary colors. Eventually, however, robes came in all kinds of colours and patterns. ${ }^{88}$ The ultimate kạsāya was the "purple robe" (shie 紫衣) offered to eminent monks by the Emperor. We are told that Dōgen had mixed feelings about receiving such a robe from Emperor Go-Saga 後㟍峨. However, unable to refuse it - although it was clearly a Chinese innovation-he merely wrote a poem expressing his embarrassment. ${ }^{89}$

\section{The field metaphor}

The division of the robe into strips gave rise to one of the main topoi, namely, the description of the robe as a field, and more precisely a "field of merit" (fukuden 福田). The robe is sometimes called densō-e 田相衣 ["a robe having the form of a field"]. According to the Sangoku sôden fukuden kirigami 三國相傅福田 切紙 [Kirigami of the Field of Merits Transmitted in the Three Countries], an initiation document allegedly transmitted by Rujing to Dōgen: "The Buddha said:

${ }^{85}$ T. 45, 1900: 899a3.

${ }^{86}$ See Kennedy, op. cit.

${ }^{87}$ See Mujaku, Zenrin shokisen, 683a. According to various sources like the Fozhi liuwu $t u$, the three "impure" colours are blue, black, and "magnolia" (mulian 目莲); see T. 45, 1900: 898c. The Shakushi höe kun [ZSZ Shingi, 551] indicates that "mixing" the five colours is like adding salt to harmonize the five tastes.

${ }^{88}$ For a representative sample, see Manteau de nuages, 1992: 24-105.

${ }^{89}$ The first "purple robe" was conferred by the Empress Wu Zetian 武則天 in 690 to the monk Falang 法郎 and his group. See Antonino Forte, Political Propaganda and Ideology in China at the of the Seventh Century, Napoli: Istituto Universitario Orientale, 1976: 9-13. In Japan, the first monk to receive it was Dōgen's teacher Yōsai 㮡西. The Shakushi hōe kun insists that Dōgen, like his predecessors Fuyong Daokai and Tiantong Rujing, rejected the purple robe and wore a blue-black kāssayya his whole life. Retracing the history of the purple robe, it argues that its color, not being "impure," did not conform to the Dharma. See ZSZ Shingi, 553, 561-562. 
'On this mountain there is a field named 'field of merits.' This is because if one sows once, one reaps seven times. Its fruit is one sun of and five fen 分 long. Those who eat it never fall ill. Therefore, patterning the kașayya after this field, one names it field of merit." 90

In Dōgen's "Kesa kudoku," the Buddha describes to Jñānaprabha bhikṣu the ten merits of the käsăya. The ninth is as follows: "The kāsāya is like a good field, for it can nurture the Bodhisattva way."91 The symbolism of fertility also appears in the "Kāșaya-gāthā": "How wondrous this deliverance robe,/ Like a formless field of merits!"92 A little further, Dōgen quotes the following verse by the Buddha: "The powers of the kasa àya are inconceivable; they can nurture the Bodhisattva practice. The growth of the seeds of awakening is like spring sprouts, the wondrous fruits of awakening resemble autumn fruits."

Likewise, Mujaku quotes a Vinaya commentary according to which "the kāsāya is known in the world as the robe of the field of merits, after the model of a ricefield. In the mundane rice-fields, one irrigates the parcels to make rice sprouts grow and to nurture them. As to the field of the Dharma robe, one fills it with the Four Great Vows to help sentient beings, one increases the thought of the three types of goodness, and one nourishes the wisdom of the Dharma body." 44

This fertility symbolism is clearly overdetermined: the agricultural metaphor derives from the robe's shape, from its original colour (associated with flesh, or blood, as in the case of Bodhidharma's robe), and from the symbolism of ordination as rebirth. In many Chan texts, a similar symbolism is applied to the mind, described as a field (the mind-field, xintian 心田, or “mind-ground," xinti 心地). The image of the field also brings to mind a folkloric motif that appears in Huineng's legend, in relation with the foundation of Huineng's Baolin Monastery at Caoxi. In this tale, Huineng requires from a donor a domain of the size of his robe-which grows magically to cover the whole mountain. ${ }^{95}$

${ }^{90}$ See Ishikawa Rikizan, op. cit. (6): 106.

91 T. 82, 2582: 54b18-19.

92 Ibid., 54a 24

93 Ibid., $54 \mathrm{c} 5$.

${ }^{94}$ Zenrin shōkisen, 684 .

95 Huineng is also able to make a spring gush forth-another source of fertility, another widespread folkloric motif-by planting his monk's staff (shakujo) in the ground. See Michel Soymié, "Suurces et sourciers en Chine," Bulletin de la Maison Franco-Japonaise (n.s) 7, I (1961):1-56. Yanagita Kunio mentions other Asian variants of this motif. In the Japanese legend of Dōunji 洞零综 in Nanakitada t北用 (Miyagi prefecture), a monk asks from a donor the land that will be covered by the shadow of his staff (shakujo)), and when his wish is granted, the shadow suddenly covers the entire mountain. In the Indian legend of King Aśoka, the Buddha asks a Nāga king to give him the land on which he is sitting, and when the Nāga agrees, the body of the Buddha suddenly grows, extending to the entire country; in Ennin's 酒仁 Nyū Tó ki 入唐記, the Bodhisattva Mañjuśri manifests himself as a monk and asks the emperor to give him the land covered by his sitting mat; when the emperor agrees, it 
In another kirigami, the symbolism of the field (or, more precisely, of the SinoJapanese character for "field,") is described as a combination of two swastikas, clockwise and counterclockwise:

Standing up, the master draws a circle. Then sitting down, he asks: "What does it mean?" Answering in place [of the disciple]: "Vertically, it reaches the three extremes, horizontally it pervades the ten directions." The master says: "At such a time, what then?" Answering instead: "Ah! Its head has come out beyond heaven!"

Standing, the master draws a circle; then he sits down for a while and says: "Again one draws a clockwise swastika and a counterclockwise swastika; if one unites them, they form the character 'field.' This is the robe of the formless field of merit 记斥田." 96

\section{The robe as a relic}

The kāsayya is what we could call a contact relic. If the robe, like various other contact relics, came to legitimize the transmission ritual, it is because it was perceived as a substitute of the sarira, in other words, as a substitute body of the Buddha. The similarity between the robe and the sarira of the Buddha is suggested by various hagiographical accounts. In Keizan's Denkōroku, for instance, when a king attempts to burn the kâsāya transmitted by Simhabhikșu to Basiasita, the robe emits a five-coloured light. The failure of the king to destroy the robe leads him to conversion. The failed attempt of a king to destroy the sarira, and the sarira's emission of a five-colour light, are topoi of Chinese Buddhist hagiography. ${ }^{97}$ Although at first Dōgen held śarira in high respect, in particular when he brought back to Japan the relics of his teacher and friend Myōzen 明全, he eventually rejected them, apparently to distance himself from the rival Darumashū 達摩宗, a school in which the cult of relics played a great importance. ${ }^{98} \mathrm{His}$ criticism of the sarira is expressed in the following passage of "Den'e": "Relics can be found in cakravartin kings, in lions, in men, in pratyeka-buddhas, etc.; but not the kāsâya, which only the Buddhas possess. While imbeciles esteem sarira, they ignore the kāsāya, and few are those who know that one must preserve it." 99 And Dōgen concludes: "To have seen and worshipped now the kāsa yay is to have seen the

will in turn extend over five hundred li. See Yanagita Kunio Zenshū 柳田國男全集, Tōkyō: Chikuma shobō, vol. 7 (1990): 140-141.

${ }^{96}$ See Ishikawa, "Chūsei Sōtōshū kirigami no bunrui shiron (14)" Komazawa Daigaku bukkyō gakubu ronshū 19 (1988): 119. Swastikas are also sewn on the kāsāya, at the corners of the eight joints (setsu 節). See Sanyi xianzheng $t u$ 三衣顯正圖, in $Z Z$ 105: 253a-255a.

${ }^{97}$ Keizan's actually quotes the Jingde Chuandenglu, T. 51, 2076: $215 \mathrm{a}-\mathrm{b}$.

${ }^{98}$ See Faure, "Dōgen, the Darumashū, and Sōtō Zen," Monumenta Nipponica 42, 1(1987): 25-55.

${ }^{99}$ T. 82, 2582: $56 \mathrm{c} 13$. 
Buddha. While erecting myriads of stuppas, one must make offerings to this robe of the Buddha." 100 In the Shōbōgenzō zuimonki, too, Dōgen downplays the soteriological importance of relics. ${ }^{101}$

\section{The robe as a mandala}

As noted above, the field metaphor gives rise to all sorts of glosses concerning the five, seven, nine, or twenty-five strips of cloth that make it up. The central strip is a kind of axis mundi through which other strips are symmetrically reflected. ${ }^{102} \mathrm{~A}$ form of numerical exegesis also goes on: a robe made of five strips is said to be for the "practice of the Way" because the number five represents the five Buddhas and the five wisdoms. This is why it can fend off the five desires, the five passions, and allow one to obtain the five powers and the five knowledges. The kassayya thus becomes a kind of microcosm, or more precisely a cosmogram. In the Kesamandara kirigami 袈裟曼茶羅切紙 [Kirigami of the Kāșāya Mandala], the robe is assimilated in its finest details to a mandala, and thus becomes the symbol (and mnemonic device) for the metaphysical universe. As noted earlier, the squares (shiten or kakuchō) at the four corners inside the kāsa àya frame correspond to the four protective gods (lokapala), while the outer borders correspond to the four oceans; the vertical strips to the nine worlds, and the horizontal strips to the Buddhas, the Bodhisattvas, the two esoteric mandalas, and the fields of merit formed by the Arhats and the Bodhisattvas of the Ten Stages. ${ }^{10.3}$ A similar diagram is found in a document entitled Kesa daiji 袈裟大事 [var.: 克], transmitted by Shōdō 紹道, the ninth abbot of Shōryūji 正龍寺 in Saitama prefecture [see illustration].

The Fukuden-e kirigami quotes the following passage of the Daibibasharon [Mahāvibhāsā]: "The kāssayya in a Buddha-land is like the sun and the moon in the world. The nine-strip robe is the bodhimanda of the 350 Buddhas; the seven-strip robe that of the 215 Buddhas; the five-strip robe that of the 130 Buddhas; the gold embroidered robe was sewn by Gautami, the adoptive mother of Sākyamuni."104

Again, according to the Eihei kaizan goden zagu mon 永平開山御傳坐具文:

The five-strip kāṣaya expresses the five Buddhas and manifests the five wisdoms; the thirty-five Buddhas reside within it, and this is why this kāsanya transcends the five desires, cuts off the five passions, obtains the five supernatural powers, and reaches the five wisdoms; it is the kâsayya that all the Buddhas of the three periods have transmitted to each other. Thus it is

${ }^{100}$ Ibid., $56 \mathrm{~b} 26$.

101 See Masunaga, 1975: 5: "As I see it, relics should be reverenced, since they represent the Tathāgata's image and his remaining bones. It is wrong, however, to expect enlightenment just by worshipping them." [Unlike in the case of the kāsāya].

102 See Alan Kennedy, "Le Kesa," in Manteau de nuages, 1991:12.

${ }^{103}$ See Ishikawa, op. cit. (6): 108-109.

104 Ibid., 108. 
called the robe of peregrination [gyōdo 行道], or robe of work [samu 作務]. Because it is a kașayya for all times, I have now received it.

The seven-strip robe expresses the seven Buddhas, manifests the seven bodhis, the seven saintly aptitudes [shōzai 聖財], the seven equal bodhyangas; wisdom is contained in it. It is called the robe for meals. With this kāssaya, the food of pleasure in Dharma and of bliss in dhyāna fills one's heart. Thus, it is externally free from the seven obstructing sins; internally, it achieves the seven kinds of goodness. This is the kașaya sewn by the 235 Buddhas, and transmitted by all the Buddhas of the three periods; and I have now received it.

The nine-strip robe is the robe with which all the Buddhas in the three periods have preached the Dharma. ... He who wears this robe sewn by the 305 Buddhas possesses the consciousness of the Tathāgata, the perfect wisdom. He transcends all thoughts of desire for the nine realms and obtains the stage of subtle awakening [myōkaku 妙覚]. Because it is the kāsāya of deliverance of all the Buddhas in the three periods, I have now received it. ${ }^{105}$

Thus, the robe is a mandala, a symbol of the universe, but it is also a bodhimanda, a ritual area of enlightenment. Folded, it can be used as a seat for meditation, a symbol of the vajra-seat on which the Buddha reached enlightenment. The same type of symbolism is of course found in esoteric Buddhism. ${ }^{106}$ Note also the prayers pronounced when putting on a kāșàya or taking it off. The kāṣâya clearly defines a ritual area (kekkai 結界), it transforms the body of the practitioner into a "ritual body," a bodhimanda. Even the way of holding a part of the kesa in one hand, as is shown in several paintings of the patriarchs of the Shingon sect, indicates that, like the vajra-scepter, the kassāya can become part of a mudrā.$^{107}$ Thus, putting on the kassāya means taking on a cosmic body. The royal symbolism is also expressed at times through the mandala. The Fukuden-e kirigami, for instance, contains a passage, unfortunately too fragmentary, in which the robe is described symbolically in terms of an imperial audience in the presence of various categories of officials and nobles. In the diagram of the kasa âya that accompanies the text, the strip on the upper left represents the imperial palace and its inhabitants, that on the upper right the monks and the people. The two strips also correspond to the upper and lower sections of the imperial capital, respectively. ${ }^{108}$

105 Ibid., 110.

106 The Keiran shūyosshu, for instance, assimilates the five-, seven-, and nine-strip kāsăya to the Taizōkai, Kongōkai and Susiddhi maṇualas, respectively [T. 76, 2410: 768b]. Cf. note 79.

107 See Manteau de nuage, 1991: 106.

${ }^{108}$ See Ishikawa, op. cit. (6): 106-107. 


\section{The robe as Buddha}

From being a contact relic, the kāsāya becomes by metonymic extension the Buddha himself, or at least allegedly turns the person who wears it into a Buddha. As the Nianfo jing 念佛經 points out, "The kāsāya is exactly the same as the Buddha. All the representations of the Buddha are like that, because they are identical to the Buddha." 109 The same idea is often found in the kirigami: "Those who put on the Buddhist kāsāya have the body of a Buddha." 110 The Shakushi hōe kun quotes, among the eight characteristics of the kāsāya, the fact that, exactly like the Buddha's body, it is endowed with thirty-two primary and eighty secondary marks. "II

Although this kassayya is not the original one, it is its true replica, a kind of vera icona (like Christ's "Veronica," or holy shroud). In "Kesa kudoku," explaining the method for washing the kāsāya, Dōgen argues that one must worship it as an icon: "You should burn incense, scatter flowers, walk clockwise around it several times, and prostrate yourself three, six, or nine times."112 Again, in "Den'e": "You should understand that the $k \bar{a} s \bar{a} y a$ is the Buddha-body and the Buddha-mind. It is also called the robe of deliverance." 113 Being a symbol of the Buddhist teaching, the robe, duly transmitted from a master to his disciple, becomes a scepter of authority, transforming the person who possesses it into a Buddha. According to Mujaku, the gold-embroidered kāsayya must be worn at the time of sermon, when the master ascends the Dharma Hall (jödō 上堂), that is, when he becomes ritually a Buddha. ${ }^{114}$

\section{The robe as a stūpa}

This equivalence already appears in a passage where Dōgen extols the merit of the Kașāya-gāthā: "How wonderful this deliverance robe!/ Like a formless field of merits/ It expounds the Tathāgata's teaching/ And saves all sentient beings." Dōgen's comment is significant: "After reciting this verse, one puts on the kāsāya, considering it as if it were one's master or the [Buddha's] stūpa."11s As the Buddha tells Jñānaprabha bhikṣu: "Son of the Buddha, unfold the kāsāya so that it looks like a stūpa." 116 This passage may perhaps be interpreted in the light of Xuanzang's description of the first relic worship (in this case, hair relics): "Tathāgata forthwith spreading out his Samghäti on the ground as a square napkin, next laid down his

${ }^{109}$ T. 47, 1966: 127ab.

110 Ishikawa, op. cit. (6): 106.

"I' See Shakushi hōe kun, ZSZ Shingi: 552.

112 T. $82,2582: 51 \mathrm{~b} 4-8$.

113 Ibid., 59c28-29.

114 See Zenrin shōkisen, 683a. See also Robert Sharf, "The Idolization of Enlightenment: On the Mummification of Ch'an Masters in Medieval China," History of Religions, 32, 1 (1994): 1-31.

115 "Kesa kudoku," T. 82, 2582: 54a26.

116 Ibid., 54c1. 
Uttarāsanga and then his Sarkakshikā [= antarvāsa, i.e., the three monastic robes]; again over these he placed as a cover his begging-pot, on which he erected his mendicant's staff. Thus he placed them in order, making thereby (the figure of a stüpa. The two men [the two merchants Trapusa and Bhallika] taking the order, each went to his own town, and then, according to the model which the holy one had prescribed, they prepared to build a monument, and thus was the very first Stüpa of the Buddhist religion erected." 117

The stūpa, that is, the "architectural body" or substitute body of the Buddha, is equivalent to the ritual implements possessed by the monks, and its foundation, as it were, is constituted by the three kinds of kasâaya. Whereas the "five rings stūpa" (gorinto 五輪塔), representing a symbolic or cosmological system, is counterbalanced by the "seamless stūpa" (muhōtō 無綘塔), representing the absolute, undivided realm beyond symbols, there is paradoxically (and understandably) no "seamless kāsâya." The two swastikas that constitute the image of the robe as a field also represent the two pradaksina, the clockwise and counterclockwise circumambulations around the stūpa, symbolizing the upward movement from samsāra to nirvāna, and the downward movement from nirvāna to samsāra-that is, death and rebirth.

The Shakushi hōe kun quotes a passage of the Ratnaküta-sütra, in which the Buddha explains as the first of the eight characteristics of the kāsāya its having "the form of a stūpa" (tōsō 塔相): "Because the stūpa is the Tathāgata's dharma body of six elements, the ultimate virtues, the Bodhisattva Maitreya always holds a stūpa in each hand, and Tamon Tennō 多聞天王 [Vaiśravaṇa] too always holds a stūpa. The same is true of the virtues of the kāsāya." 118

The robe as a womb

Another kirigami, the Ehatsu kechimyaku denju sahō 衣鉢血脈傳授作法, indicates that the Dharma robe and its transmission symbolize the gestation of the fetus in the womb-itself a model for spiritual gestation: 119

"Receiving the robe" means that, after spending ninety days in my father's body, I spent nine months in my mother's womb. The sequence of practice during that time is named "method for the reception of the robe". Ultimately, the robe symbolizes the ena 衣那 (placenta); one also speaks of Ena Kōjin 衣 那光神: it is the spirit that keeps bodily vitality; it is also called ujigami 氏神,

${ }^{117}$ From Samuel Beal, Si-yu-ki: Buddhist Records of the Western World, London: Trübner, 1884, reprint New York: Paragon, 1968, vol. 1: 47-48.

118 Shakushi hōe kun, ZSZ Shingi: 551-552.

${ }^{119}$ This document should be put into relation with other kirigami that interpret the episode of Sākyamuni's transmission to Kāśyapa through holding up a flower as a symbol of death and cremation. See for instance Faure, The Rhetoric of Immediacy, Princeton: Princeton University Press, 1991, 198-199. 
because it is a kami that protects the life of men. As to what is called kâsanya: I spent nine months in my mother's body, and it is the changes of that period that are revealed [by it]. The seven and nine luminaries, and the twenty-eight mansions are said to correspond to the third month, and this is expressed by the four-strip sitting mat. The fifth month is symbolized by [an alternance of] one long and one short patch, constituting a five-strip robc; this is expressed by the kara 掛落 or small robe. The seventh month is symbolized by [an alternance of] two long and one short patches, constituting a seven-strip robe; this is expressed as the "robe for meals." The ninth month is symbolized by [an alternance of] three long and one short patches, constituting a nine-strip robe; this is expressed as the great robe, or Dharma robe. In total, there are twenty-five strips which symbolize the hōshin zanmai 寶心三昧 (samádhi of the jewel-spirit). One also says that it is the rhythm of the incoming and outgoing breaths of the five elements, which is expressed by the threads of the two strings of the kassayya. Moreover, the color of the robe is made black to express the blackness of the voice-consciousness. ${ }^{120}$

Likewise, according to the Fukuden-e kirigami, "The kạsāya finds its origin in the thread of events during the time one was inside the womb."121 According to other sources, the red robe of the patriarch Bodhidharma would represent the placenta, and the nine years spent by the Indian master absorbed in samädhi are said to

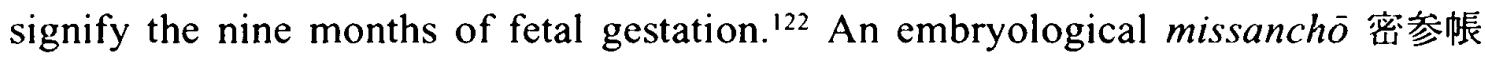
(esoteric commentary on kōans) edited by Suzuki Daisetsu is particularly worth mentioning in this context. It is a commentary on the kōan entitled "Xiangyan's 居 撖 Man Up a Tree” [Wumenguan 無門関 13]:

Question: "What about Bodhidharma's facing the wall for nine years?" Answer: "These are, in fact, the nine months spent in the womb. A season is counted as one day, or one day counts as one month. This means that a

${ }^{120}$ See Ishikawa, op. cit. (6): 109.

${ }^{121}$ See Ishikawa, op. cit. (6): 109. The term sho 緒, "thread of events," originally means the end of a silk thread. The symbolism of rebirth, which was also a predominant aspect of the Hakusan/Shirayama 过山 cult, could perhaps be connected, as Yanagita Kunio has argued, with the silk-worm, who dies in his cocoon to be reborn-if it is not killed for good by the sericulturist.

${ }^{122}$ See Sangai isshinki 三界 一心記 (ca. 1644) by Zen master Dairyū 大龍 in Washio Junkei 整尾順敬, ed., Nihon shisō tōsō shiryō 日本思想䦚争資料 V, Tōkyō: Shōwa shoin, 1930:505540. I am indebted to James Sanford for this and the following reference. In light of the above discussion, it might be relevant to note that Bodhidharma came to be associated in Japan with sericulture. In Japanese folk-art, his features are painted on a cocoon (mayu daruma 趛磨). Apart from the shape of the cocoon, which McFarland calls "Darumamorph," this association comes from the fact that both Daruma and the silkworm were seen as symbols of gestation and rebirth. See H. Neill McFarland, Daruma: The Founder of Zen in Japanese Art and Popular Culture, Tōkyō and New York: Kodansha International, 1987: 64-66. 
season has twelve seasons. One day matches up with twelve, that is, ten days are 120 days; or else one day equals one month." ... Question: "Tell me about Bodhidharma with the caul, about Bodhidharma prior to all distinctions, about Bodhidharma's nine years before the wall." Answer: "During the nine months spent in the maternal womb, the caul is put on. During the nine years of zazen 齿禪 Bodhidharma put on a skin cap-to ward off the three poisons, and to strengthen the roots of life." 12.3

The symbolism of the robe as placenta also appears in the legend of the third Indian Patriarch Śanavāsa, said to have been born wrapped in a robe, which became a $k \bar{a} s \bar{a} y a$ when he was ordained. ${ }^{124}$ A similar legend is that of the nun Śuklā, who was born with a robe, and also wore a robe after her death, during the period she spent in limbo as an "intermediary being" (antaräbhava, J. chüu 中有), waiting for rebirth. ${ }^{25}$ After mentioning these two cases, Dōgen adds the following comment: "Today, when we encounter the Buddha and leave the family, the profane robe we had from birth will naturally turn into a kāsāya, just as in the case of Śanavāsa."126

The Busso kesa ko 位祖袈残考 also quotes the story of the Chan master Yun'yan

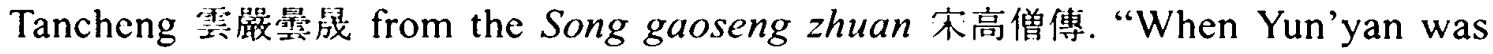
born, he wore a natural placenta robe. His right shoulder was bare, just as if he had been wearing a monastic robe. It is said in the appended [notice]: Sānavāsa in Chinese means placenta (embryo-robe). Because he was born wrapped in this robe, as an infant he did not need swaddling clothes. As he grew up, the robe adapted to his body, and when he was ordained as a monk, it became a Dharma robe. Master [Tan]cheng's placenta robe is very much like that of Śanavāsa."127

Also significant in this respect is Keizan's theory about the origin of the robe: "There are three theories concerning that kassayya. One is that the Tathāgata wore it with him from the womb." 128 The prevailing tradition, based on Xuanzang's version of the transmission legend, however, was that the robe had been given to Sákyamuni by his adoptive mother Gautami. ${ }^{129}$

The relation of the robe with the process of gestation is suggested by the inclusion of the cloths defiled by menstrual blood and by childbirth among the ten types of cloth that make first-quality funzōe. Equally suggestive is the way in which, in Karukaya [1631], “Kōya no maki 高野の卷," the story of Kūkai's mother explains the taboo against women entering the mountain (nyonin kekkai 女人結界).

\footnotetext{
${ }^{123}$ See Suzuki Daisetsu zenshū 鈴木大拙全集, vol. 1, Tōkyō: Iwanami shoten, 1968-71.

${ }^{124}$ See for instance Denköroku, T. 82,2585: 348b-349c.

125 T. 82, 2582: 50c10. See also Busso kesa ko, in ZSZ Shingi: 533.

${ }^{126}$ T. 82, 2582: $50 \mathrm{c} 6, \mathrm{c} 9$ and $54 \mathrm{c} 11$.

${ }^{127}$ Busso kesa kō, ZSZ Shingi: 533.

${ }^{128}$ See Denköroku, T. 82,2585: 347b15-16.

${ }^{129}$ See for instance the Fukuden-e kirigami.
} 
When Kükai's old mother wants to climb the mountain to see her son, the earth shakes. Kükai appears and asks her to leave, and, when she refuses and is about to proceed, he spreads his kesa on the ground and asks her to walk across it. When she does so, her menstrual blood, which had stopped flowing more that forty years ago, starts flowing again. When it falls on the kesa, the latter takes fire and carries Kūkai's mother away. ${ }^{130}$

\section{Conclusion}

The symbolic equation between the robe and the placenta is one of the most intriguing aspects of the kāsāya symbolism. ${ }^{131}$ The kāsāya also symbolizes (and is proof) of ordination, seen as abhiseka, royal consecration, and rebirth-the "king's new clothes," of flesh color. According to Paul Mus, in the Satapatha Brāhmana, it is the royal mantle that makes the king. While the king is sitting on the throne, the priest throws this mantle over him, saying, "You are the womb of kingship."132 The $k \bar{a} s \bar{a} y a$ is a kind of royal mantle. According to Mus, when Maitreya receives the golden kāsāya from Kāśyapa, it is his quality as a Buddha that he will forever put on: he will place himself in the "womb" of the dignity of Buddha; and he will again follow the rites of royal consecration. ${ }^{133}$

The symbolic equivalence between the kāsāya and the stūpa also reminds us of Paul Mus' analysis in his Barabudur. We find not only the same womb symbolism, but also the same numerical symbolism in both cases: like the kāsāya, the stūpa is a mandala and/or a bodhimanda. ${ }^{134}$ In the end, all these symbols point to different aspects of the same notion: to put on a kassāya means not only to become a monk but also to receive the abhiseka, to be reborn as a cosmic ruler, a cakravartin king, as a living icon, and to become "a Buddha in this very body."

By the constant material handling of ritual objects and the ideological manipulation of the symbols adhering to them, the Zen adept gradually learned how to read through

${ }^{130}$ See Susan Matisoff, "Holy Horrors: The Sermon Ballads of Medieval and Early Modern Japan," in James Sanford and William LaFleur, eds., Flowing Traces: Buddhism in the Literary and Visual Arts of Japan, Princeton: Princeton University Press, 1992. In other variants, Kükai's mother is saved by her son.

131 Nevertheless, in the story of Kükai's mother, it is the robe that prevents the mother, made impure by her menstrual blood, from setting foot on Mount Kōya.

132 Paul Mus, Barahudur, 2 vols., Hanoï: Imprimerie d'Extrême-Orient, 1935. Reprint New York: Arno Press, 1978; Paris: Arma Artis, 1990, 426.

1.33 Ibid., 427.

134 One could evoke another suggestive work of Paul Mus, "Le Buddha paré," BEFEO 28 , 1-2 (1928): 153-278. Just as the icon of the Buddha is decorated in order to signify the Buddha in his sambhoga-kāya, the monk wearing a kāsăya is no longer, at least symbolically, a human being, but a glorified Buddha. 
the superposed symbolic systems, using the logic of the Two Truths, and to move from one symbolic system to another. The truth of these systems lies in their relationship to each other, and the Zen master, who was supposed to reject all symbolic mediation, is himself above all a mediator, a symbolic shifter. Still, cosmological symbolism, far from being the private property of Zen, forms the common basis of all Sino-Japanese culture, a sort of symbolic syntax that does not imply on the part of those who use it any deep faith but rather a kind of weak, generalized belief. In certain cases it is nothing more than a common cultural reference to which one should not attach much hermeneutic importance. Nevertheless, belief in the talismanic value of certain ritual objects seems, in turn, sufficiently deeply rooted to hold in check or subvert any attempt to demythologize the tradition.

We must finally question the relevance of this symbolism to actual practice. The fact that it plays such a prominent role in Sōto kirigami seems to attest to its ritual importance, but we lack evidence of the actual use of this symbolism from other contemporary documents. The analysis of the underlying symbolic system should not be pushed too far. Probably the anonymous authors of the kirigami were not aware of all the implications of this system. But, as Jacques Le Goff has argued, "a symbolic system can be fully effective without explicit awareness." 135 Are we then faced, as Le Goff insists, with a realm of mentalities "rife with distortions, psychic automatisms, survivals and rejects, and obscure, incoherent thoughts erected into pseudo-logical systems"? ${ }^{136}$ It seems that we are dealing more with a "practical logic," in the sense used by Pierre Bourdieu, and thus with an attitude that does not deserve to be discredited as "pseudo-logical," as is too often done. Furthermore, despite all these attempts to "sacralize" the kāsasya, and the warnings of heavenly punishment for lack of respect, the robe was often treated rather casually by the monks themselves, as we can see from the comments of the author of the Shakushi hoe kun. ${ }^{137}$ Thus, the ideology finds its limits in real practice.

One of the main functions of the kāsa âya, throughout its history, was to legitimize orthodoxy, or sectarianism: not only that of the Buddhists vis-à-vis the nonBuddhists, or the orthodox transmission of the Chan/Zen school, or a certain Zen sect or branch (like Sōtō), but the superiority of monks over laymen. Actually, as its symbolic value increased, it came to legitimize monastic misbehavior: because of the magical power of the kāssāya, it is better to be a monk-however depraved-than a layman-however virtuous. As often in Japanese culture, the wrapping is more valuable than the content: the magic power of the robe provides the ultimate argument for respecting depraved monks. ${ }^{138}$ We have here a paradox

135 Jacques Le Goff, Time, Work, and Culture in the Middle Ages, transl. Arthur Goldhammer, Chicago: University of Chicago Press, 1980: 269-270.

${ }^{136}$ Le Goff, ibid., 71.

137 Shakushi hōe kun, ZSZ Shingi: 569-570.

138 See for instance Robert Morrell, Sand and Pebbles, Albany: S.U.N.Y. Press, 1985: 194-196. 
that does not seem to have worried Dōgen, for whom it seems better to transgress monastic precepts than to remain a layman or lay woman: "The fact that this nun Utpalavarnā was able to reach Arhathood has originally nothing to do with her own merits. It is entirely due to the merits of her having once worn as a joke this kassāya that she now obtained awakening." 139

However, the robe also symbolizes the Bodhisattva Precepts which can be given to laymen. Dōgen himself, despite his emphasis on monkhood, admits the value of these precepts and seems therefore to admit the possibility, thanks to the magical power of the kassäya, of a kind of lay holiness, halfway between profane laicity and monastic sacrality.

Thus, contrary to the French proverb according to which "l'habit ne fait pas le moine," we can now see that, in medieval Buddhism, the kāsâya "does make" the monk, or better, the Buddha. For all its alleged "purity," Dōgen's Zen paved the way for the kind of hermeneutic drift or proliferation that came to characterize the kirigami of the later Sōto tradition. The ritualization of everyday acts, for which he was instrumental, led naturally to symbolic suprescription and to the "sacralization" of Zen.

It seems therefore arbitrary to reduce, as the proponents of "critical Buddhism" (hihan bukkyō 批判伀教, a misnomer for "polemical Buddhism") have done recently, the thought of Dōgen, as expressed in the twelve-fascicle Shōbogenzō, to the orthodox teaching of "co-dependent arising" (pratityasamutpäda). Incidentally, this "philosophical" formula was inserted into statues and reliquaries, among other relics, by eminently orthodox Buddhist masters. We need only read other fascicles of the same work, like “Kuyō shobutsu 供養諸佛," to realize that Dōgen himself, who seems to have been occasionally inscribing spring talismans (risshun daikichi 立春大古), was probably not a total stranger to similar practices. One may wonder if the short-sightedness of modern apologetes is not caused by their wearing a kāsāya on their head, in the orthodox Chinese fashion described by Dōgen.

Leaving polemic aside, the evolution of the kāsăya seems related to two departures from the early tradition: symbolization and aestheticization, with the use of increasingly rich materials (essentially silk) and sophisticated imagery. During the Edo period, a reaction against these two trends (which led to Sōtō kirigami and to Nishijin 晒陣 brocade) took place, with a return to a more sober kāsa $\bar{y} a$, called nyoho-kesa 如法袈梁 [“kasāya in conformity with the Dharma”]. This type of kāṣāya was first advocated by Buddhist scholars like Jiun 慈雲 (1718-1804), and soon in Sōtō itself. We have from this period various kașāya made from linen (asa 森), a plant fiber that seems more appropriate - although much less easy to dye and decorate-than silk.

There seems to have been an ongoing debate between Chan/Zen and Vinaya regarding this point. The author of the Lüzong huiyuan, a work based on Daoxuan's

${ }^{139} T .82,2582: 52 b 14-16$. 
interpretation of the Dharmaguptaka-vinaya, criticizes the Chan monks of his time who, while claiming to be Mahāyāna adepts not attached to form, go against the Buddha's teaching. On the other hand, he singles out two Chan masters, Nanyue 南 獄 and Daoxiu道休, as examples of eminent monks who respected this teaching by wearing only mugwort material. He quotes a commentary by Daoxuan saying that Indian monks do not use silk to make kāsāya. ${ }^{140}$

Conversely, the Chan/Zen criticism of Daoxuan and of his successors was repeated throughout the Edo period by Sōto scholars, even by an advocate of a return to the traditional funzō-e like Mokushitsu 然窒 (1775-1833). The Den'e zōbi shöhaka 傅衣参莮章巴歌 criticizes Lingzhi 霊芝 and Yuanzhao, the authors of the Fozhi biqiuliuwu tu (T. 1900), for relying on Daoxuan, despite Dōgen's criticism of the latter. According to these authors, the way of sewing and wearing the kāsa âya, newly devised in the Chinese Vinaya school, is non-orthodox because it relies on oral instructions given by a celestial being to Daoxuan. Furthermore, the same Liuwu tu criticizes Chan monks for wearing a nine-strip kāṣāya. The nine-strip $k \bar{a} s \bar{a} y a$ mentioned by Dōgen in "Den'e" is not the same as the one mentioned by these Hinayāna teachers. Therefore, the heirs of Dōgen should never use the Fozhi biqiu liuwu tu. ${ }^{141}$ Likewise, Mokushitsu's Hōfuku kakushō 洼服格正 criticizes Daoxuan and the Fozhi biqiu liuwu tu. ${ }^{142}$ The Shakushi hòe kun, too, criticizes Daoxuan and Yuanzhao for rejecting the use of silk. It argues that Daoxuan, although he was an eminent Vinaya master, went against the Buddha's teaching. This teaching, on the other hand, was preserved by Yijing, a contemporary of Daoxuan who had the advantage of first-hand experience of Indian Buddhism. Based on that experience, Yijing approved the use of silk, while Daoxuan rejected it on the basis of a vision. But, as Dōgen argued, the disciples of the Buddha should teach to divine beings, not be taught by them. In the end, Daoxuan and his epigons are Hinayāna followers, who do not understand the teaching of Mahāyāna. This conclusion is somewhat paradoxical, as Daoxuan's Vinaya, although inspired from the Dharmaguptaka, was much closer to the Mahāyāna than that of a conservative like Yijing. ${ }^{143}$ The ideological filiations become even more surprising, since Dōgen, while he opposes the dominant Vinaya tradition stemming from Daoxuan and seems to agree with Yijing, will later see his arguments taken up by a relentless critic of Buddhism such as Tominaga Nakamoto 富永仲基 (1715-1746), in his ironic comments about Buddhist vegetarianism. ${ }^{144}$

${ }^{140}$ Lüzong huiyuan 律宗會元, ZZ 105: 415.

${ }_{141}$ Den'e zōbi shōhaka, ZSZ Shingi, 608, 615.

142 Höfuku kakushō, ibid., 665.

14.3 Shakushi höe kun, ibid., 564-565.

144 Tominaga writes for instance in his Shutsujo kōgo 出定後語: “Now we are allowed to eat cereals and vegetables and only meat is forbidden. Why are the Buddha and the bodhisattvas so unfair?" See Tominaga Nakamoto, transl. Michael Pye, Emerging from Meditation, Honolulu: University of Hawaii Press, 1990: 140. 
As Alan Kennedy aks: "Can a richly decorated kesa represent the Buddhist teaching? And if so, does it represent it to a lesser degree than a more sober kesa?"'45 Kennedy's answer to this rhetorical question is that the Buddha himself wore different kinds of kāsāya at various times in his life. Śākyamuni was not only (or always) an ascetic, a world-renouncer, wearing a funzo-e, he was also (and pcrhaps above all) a royal figure, a world-conqueror, wearing a soggyari-e 僧伽梨衣. Even morc so in the Mahäyāna context, where we are dealing not only with the "historical" Buddha, but with metaphysical Buddhas in their "glorious bodies."

Nevertheless, this ambiguity created a tension between two different images of Buddhism, a tension exacerbated by the necessity to transgress one of the fundamental precepts of Buddhism, that of not killing life, in order to obtain the material most appropriate to express the regal aspect of Buddhism. ${ }^{146}$

\section{List of abbreviations}

$\begin{array}{ll}\text { DZZ } & \text { Dōgen Zenji Zenshū } \\ \text { JDZ } & \text { Jōsai Daishi Zenshū } \\ \text { SZS } & \text { Zoku Sōtōshū Zensho } \\ T . & \text { Taishō Shinshū Daizōkyō } \\ Z Z & \text { Zoku Zōkyō }\end{array}$

145 Alan Kennedy, 1991: 22.

146 The gruesome reality so conveniently denied by Yijing and Dögen in the name of a higher truth struck me when visiting a silk factory in Hangzhou in the spring of 1994. Whatever Dögen may say, it becomes hard to wear silk after such an experience, even if (or because?) one is not a Buddhist. 


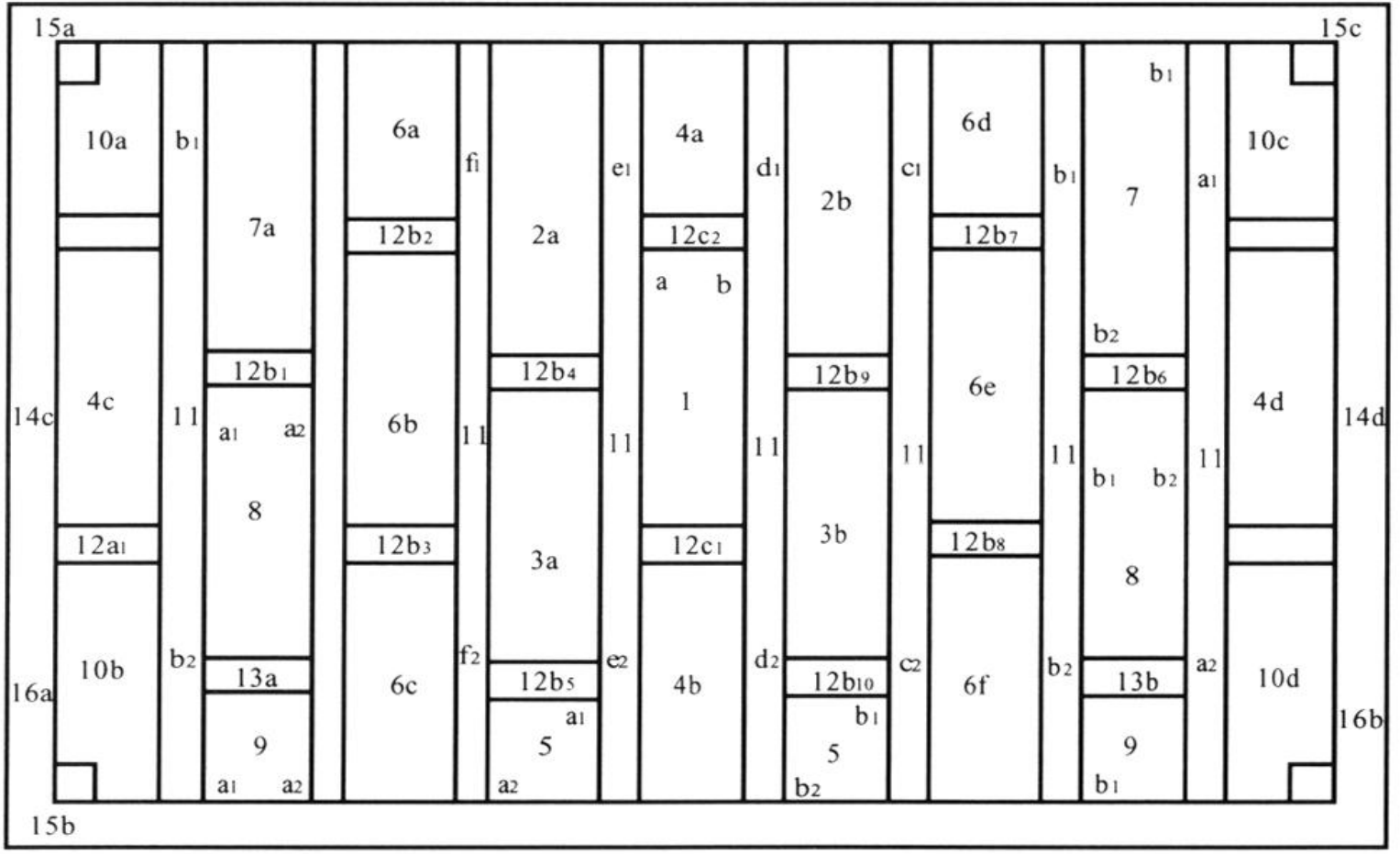

The kāṣāya mandala

1. a. Makabirushana butsu [Buddha Mahāvairocana] b. Pure Land of the Vulture Peak of Sākyamuni Buddha

2. a. Gakkō bosatsu [Bodhisattva Candraprabha] b. Nikkō Bosatsu [Bodhisattva Süryaprabha]

3. a. Kongōkai mandara [Vajradhātu maṇdala] b. Taizōkai mandara [Garbhadhātu maṇdala]

4. a. Hōshō Nyorai [Tathāgata Ratnākara?], South b. Fukūjōjū butsu [Buddha Amoghasiddhi], North c. Ashuku butsu [Buddha Aksobhya], East d. Muryöju bosatsu [Bodhisattva Amitāyus], West

5. al Kanjizai bosatsu [Bodhisattva Avalokiteśvara] a2. Jikyū dōji

b1. Kongō Zaō bosatsu

b2. Zenzai dōji [Sudhāna]

6. The past Buddhas

a. Bibashi butsu [Buddha Vipaśyin]

b. Shiki butsu [Buddha Sikkhin]

c. Bishabu butsu [Buddha Viśvabhū]

d. Karakusonda butsu [Buddha Krakucchanda]

e. Kunagon butsu [Buddha Kanakamuni]

f. Kashō butsu [Buddha Kāsyapa]

7. a. Jizō bosatsu [Bodhisattva Kșitigarbha] b1. Miroku bosatsu [Bodhisattva Maitreya] b2. Daibon tennō [Deva-king Brahma]

8. al. Superior Field of Merits of all Bodhisattvas a2. Monju bosatsu [Bodhisattva Mañjuśri]

b1. Field of Merits of the Precious Repository of all Tathāgatas

b2. Fugen bosatsu [Bodhisattva Samantabhadra]

9. a l. Idaten [Skanda]

a2. Field of Merits of the Eight Assemblies of Heavenly Nāga

bl. Earth god
10. The four Lokapāla

a. Daizurata tennō [=Jikokuten, Dhṛtarāśtra]

b. Bishamon tennō [Vaiśravana]

c. Binurokusha $[=Z \bar{o}$ chōten, Vinüdhaka]

d. Birubakusha [=Kōmokuten, Virūpakşa]

11. The nine realms

a1. Second realm a2. River of Eight Tastes

b1. Third realm b2. River of silver water

c1. Fourth realm c2. Lion's head river

d1. Sixth realm d2. Horse-head river

e1. Seventh realm e2. Ox-head river

f1. Eighth realm f2. Woman of life river

gl. Ninth realm g2. Sweet dew river

12. The fields of merits [fukuden]

al. Shuda[on]dō [srotāpanna]

a2. Shidagon [sakrdãgamin]

a3. Anagon [anāgamin]

a4. Arakan [Arhat]

b]-10: Ten bhūmi

cl. Tōgaku

c2. Myōkaku

13. a. River of the twelve nidana

b. Six pāramitā

14. The four seas
a. Southern sea
b. Northern sea

c. Eastern sea

d. Western sea

15. The four Deva
a. Hekiten
b. Kūten
c. Suiten [Varuna] 